ZOOLOGIA 31 (6): 541-556, December, 2014

http://dx.doi.org/10.1590/S1984-46702014000600003

\title{
Taxonomic revision of Parampheres (Arachnida: Opiliones: Gonyleptidae)
}

\author{
Bruno Jacob Mori \& Ricardo Pinto-da-Rocha
}

Departamento de Zoologia, Instituto de Biociências, Universidade de São Paulo. Caixa Postal 11461, 05422-970 São Paulo, SP, Brazil. Email: bjmori@gmail.com; ricrocha@usp.br

\begin{abstract}
Parampheres Roewer, 1913 is a relatively common genus of South American harvestmen. This genus is easily diagnosed by the remarkable yellow patches on the prosoma. Nonetheless, species determination within this group is challenging due the convoluted taxonomic history of the group and lack of a recent revision. In this study we revise Parampheres and describe a new species, Parampheres tenebris sp. nov., from Parque Nacional da Serra Geral, Rio Grande do Sul, Brazil. The new species can be distinguished from the other species of the genus by having dorsal scutum dark, and apophysis of coxa IV of male elongated. Furthermore, we propose the following new synonymies: Callampheres boliviensis Roewer, 1913, Pertyana ronae Mello-Leitão, 1927 and Parampheres tibialis Roewer, 1917 with Parampheres pectinatus Roewer, 1913. Parampheres now includes four species distributed from southern Brazil to adjacent areas in Argentina and Uruguay. In addition, we present a phylogenetic hypothesis based on morphological characters that supports the transfer of Parampheres from Gonyleptinae to Caelopyginae.
\end{abstract}

KEY WORDS. Brazil; harvestman; Neotropical region; systematic; taxonomy.

Within arachnids, the order Opiliones is the third in richness, with approximately 6,500 described species in four suborders (Pinto-Da-Rocha \& GiRibet 2007). The largest suborder is Laniatores, of which Gonyleptidae is the richest in number of species and the most diverse in terms of morphological shapes. The family is divided into 18 subfamilies, which occur in Central and South America. Seven of these subfamilies have been revised over the past years: Caelopyginae (PINTO-DA-Rocha 2002), Bourguyiinae (Yamaguti \& Pinto-Da-Rocha 2009), Goniosomatinae (DASILVA \& GNASPINI 2009), Hernandariinae (DaSilva \& PinTo-DARocha 2010), Sodreaninae (Pinto-da-Rocha \& Bragagnolo 2010), Heteropachylinae (Mendes 2011), and Tricommatinae (KurY 2014).

When Caelopyginae was revised (PINTO-DA-ROCHA 2002), it did not include Parampheres (Roewer, 1913) (PINTO-DA-RochA et al. 2014). The species of this genus are relatively common in southern Brazil, Uruguay and northeastern Argentina. They are easily recognized by the presence of two large yellowish orange patches on the prosoma, lateral to the ocularium.

Carl Friedrich Roewer described Parampheres pectinatus in 1913, from Santa Cruz (Rio Grande do Sul, Brazil). Later, he added Parampheres tibialis Roewer, 1917 to the genus, based on a specimen supposedly collected in Santos (São Paulo, Brazil). Another species, Parampheres boliviensis Roewer, 1917, was described by Roewer (1917), from Chaco, Bolivia. This locality record is considered doubtful, since no other specimen has ever been collected there. Also, the chaco vegetation differs substantially from that of other localities where this genus is known to occur. The remaining valid species (KuRY 2003), all from southern Brazil, were described by Cândido Firmino MelloLeitão: P. ronae (Mello-Leitão, 1927), P. bimaculata (Mello-Leitão, 1932) and P. lucidus (Mello-Leitão, 1940).

The remarkable similarity between some species of Parampheres raises questions about their validity, particularly when the troubled taxonomic history of the group is taken into account (see subfamily-level revisions cited above). For instance, KuRY (2003: 135) argued that the differences between species are so subtle that they might correspond to mere intraspecific variations of a single, widespread species.

Although there have been recent studies on the distribution, behavior and physiology of Parampheres (GonzÁles et al. 2004, Hara \& Gnaspini 2003, Stanley 2011), identification of the included species is not an easy task, since descriptions and illustration are not very informative. The last revision of the genus, which only included redescriptions of some species, was published by Soares \& SOARes (1985).

The subfamily placement of Parampheres is controversial, which can be explained by the few number of characters used during the last century to distinguish Caelopyginae from Gonyleptinae. Sørensen (1884) first proposed the use of pedipalp characters to separate the two subfamilies. Subsequently, he argued that, except for specific cases, the chelate shape of the pedipalp was not consistent enough to separate the two groups (HeNRIKSEN 1932: 279). In the identification keys constructed by Roewer (1913), the claws of tarsi III and IV, which are smooth in Gonyleptinae and pectinated in Caelopyginae, were used to distinguish between the two subfamilies. Based on this dichotomy, P. pectinatus was placed in Caelopyginae. MeLLo-LeiTão 
(1949) advocated the use of pedipalp morphology to ascertain subfamily affinities, although he described different species of Parampheres in Caelopyginae, Gonyleptinae, and Pachylinae.

SoARes \& SoAres (1985) questioned the use of smooth or pectinated claws to separate among Caelopyginae and Gonyleptinae, arguing that it is common to find both states within the same genus or even among conspecifics. They also rejected the morphology of the pedipalp as a source of diagnostic features. However, they proposed the use of the tarsal counts: the fewest number of articles is found in Gonyleptinae, whereas the greatest is found in Caelopyginae. Based on this criterion, they transferred Parampheres from Caelopyginae to Gonyleptinae. However, a molecular-based phylogenetic analysis (PInto-DA-Rocha et al. 2014) recovered Parampheres bimaculatus Roewer, 1943 as a member of Caelopyginae, supporting Roewer's (1913) original proposal.

In this paper we revise Parampheres, including updated redescriptions of species, new distribution records, an identification key and the description of a new species. Additionally, we present a new phylogenetic hypothesis, based on morphological data, to test the subfamily placement of the genus within Gonyleptidae.

\section{MATERIAL AND METHODS}

\section{Taxonomy}

In this systematic revision we analyzed 320 specimens from the following institutions: MZSP (Museu de Zoologia da Universidade de São Paulo, São Paulo, Brasil, curator: R. Pintoda-Rocha); MNRJ (Museu Nacional da Universidade Federal do Rio de Janeiro, Rio de Janeiro, Brazil, the private collection of Helia Soares was incorporated in this institution been cited as MNRJ-HS, curator: A.B. Kury); MCNRS (Museu de Ciências Naturais, Fundação Zoobotânica do Rio Grande do Sul, Rio Grande do Sul, curator: Ricardo Ott); MACN (Museo Argentino de Ciencias Naturales Bernardino Rivadavia, Buenos Aires, Argentina, curator: Abel Pérez González); MNHN (Museo Nacional de Historia Natural, Montevideo, Uruguay, curator: Miguel Simó); FCE (Facultad de Ciencias, Universidad de La Republica, Montevidéu, Uruguay, curator: Miguel Simó).

Specimens were examined in 70\% ethanol or dried. Drawings were made with a camera lucida coupled with a stereomicroscope Leica MZ75. Photographs of live animals were taken with a digital camera Cannon EOS Digital Rebel XS. Photomontage images were obtained with a Leica DFC 290 coupled with a stereomicroscope Leica M125, using the Leica Suite 3.3.0 software application. The penises of specimens were observed under an optical microscope Axioskop 2 plus. Scanning electron micrographs were obtained with a Zeiss DSM 940 scanning electron microscope (IBUSP) and prepared according to PINTO-DA-Rocha (2002).

The following abbreviations were used in synonymic listings: (biol) biological aspects; (cat) catalog; (cit) citation; (desc) description; (rdes) redescription; and (syst) systematic discussion. Measurements are in millimeters, unless otherwise specified.

\section{Cladistics}

The cladistic analysis was performed using the data matrix of Pinto-Da-Rocha (2002) and modified by DaSilva \& PintoDa-Rocha (2012) and Mendes \& Barros (2013). It includes 58 characters, which were coded for all species that are represented by males. Two additional outgroups were included: Gonyleptes saprophylus Mello-Leitão, 1922 (Gonyleptinae) and Promitobates bellus (B. Soares, 1945) (Mitobatinae). The tree was rooted on $P$. bellus because this species does not belong to the K92 clade, which is composed of Caelopyginae, Gonyleptinae, Hernandariinae, Progonyleptoidellinae and Sodreaninae (see PINTO-DA-Rocha et al. 2014).

The data matrix (42 taxa, 63 characters, Table I) was built using NDE 0.5.0 software (PAGE 2011) and the cladistic analysis was performed using TNT 1.0 (Goloboff et al. 2008). The analysis was conducted using 10,000 random addition sequences with 100 trees saved per replicate. The swapping algorithm was tree bisection reconnection (TBR). The consensus cladogram was obtained using Winclada version 1.00.08 (NIXON 1999). Characters were equally weighted and treated as unordered or non-additive, and 12 of them are multistate.

We added five new characters to the data matrix, as follows: 59) Large colorful spots on each side of prosoma: 0 , absent; 1, present. 60) Area IV: 0, absent; 1, present. 61) Armature of posterior margin: 0 , unarmed; 1 , with a large median tubercle. 62) Armature of free tergites: 0, unarmed; 1, with a large median tubercle. 63) Subapical projection on penis' stylus: 0, absent; 1 , present.

\section{TAXONOMY}

\section{Parampheres Roewer, 1913}

Parampheres Roewer, 1913: 345 (desc); 1923: 534 (rdes); MelloLeitão, 1923: 177 (cat); 1926: 359 (key); Roewer, 1931: 136 (cat); Mello-Leitão, 1932: 386 (rdes); 1933: 147 (rdesc); Soares \& Soares, 1948: 577 (cat, syn Cezarella Mello-Leitão, 1932); Ringuelet, 1959: 395 (cat, rdes); Soares \& Soares, 1985: 158 (rdes, syst, syn Pertyana Mello-Leitão, 1927); Kury, 2003: 135 (cat, syn Callampheres Roewer, 1931); Pinto-da-Rocha et al., 2012: 54 (syn. Metapachyloides Roewer, 1917). Type species Parampheres pectinatus Roewer, 1913 by monotypy.

Metapachyloides Roewer, 1917: 120; 1923: 431 (rdesc); MelloLeitão, 1926: 343 (key); Roewer, 1929: 187 (key); Mello-Leitão, 1932: 215 (rdesc); 1935: 101 (cit); 1936: 24 (syst); Soares \& Soares, 1954: 276 (cat); Muñoz-Cuevas, 1973: 226 (syst). Type species Metapachyloides rugosus Roewer, 1917 by monotypy.

Pertyana Mello-Leitão, 1927: 18 (desc); Roewer, 1930: 422 (cat, rdes); Mello-Leitão, 1932: 256; 1935: 103 (cat); Soares \& Soares, 1949: 208 (cat); Soares \& Soares, 1985: 159 (syst). Type species Pertyana ronae Mello-Leitão, 1927, original designation. 
Table I. Data matrix for the species of Caelopyginae and outgroups.

\begin{tabular}{|c|c|c|c|c|c|c|c|}
\hline Promitobates bellus & 1110000010 & 0000001010 & 0100100000 & 0110000000 & 2000000100 & 0000000000 & 200 \\
\hline Hernandaria heloisae & 0000000000 & 0000000000 & 0000000000 & 0000000000 & 0000000000 & 0000000001 & 200 \\
\hline Sodreana sodreana & 0000000000 & 0000000000 & 0000000000 & 0000000000 & 0000000000 & 0000000000 & 000 \\
\hline Sodreana inscripta & 0000000000 & 0000000000 & 0000000000 & 0000000000 & 0000000000 & 0000000000 & 000 \\
\hline Cadeadoius niger & 0000000000 & 0000000000 & 0000000000 & 0000000000 & 0000000000 & 0000000000 & 000 \\
\hline Heliella singularis & 0000000000 & 0000000000 & 0000000000 & 0000000000 & 0000000000 & 0000000000 & $? 00$ \\
\hline Iguapeia melanocephala & 1000000000 & 0000000000 & 0000000000 & 0000000000 & 0000000000 & 0000000000 & 000 \\
\hline Progonyleptoidellus striatus & 1000000000 & 0000000000 & 0000000000 & 0000000000 & 0000000000 & 0000000000 & 000 \\
\hline Ampheres fuscopunctatus & 1001001110 & 0001000001 & 0110111200 & 0001000011 & 0000100100 & 0000011000 & 000 \\
\hline Ampheres leucopheus & 1000001110 & 0001000000 & 0000111200 & 0001000011 & 0000100100 & 0001100000 & 000 \\
\hline Ampheres luteus & 1000001110 & 0001000001 & 0110110000 & 0001002011 & $00 ? 0200000$ & 0001011000 & 000 \\
\hline Ampheres tocantinus & 1000011110 & $00 ? 1000011$ & $? 000111100$ & 0001002011 & $00 ? 0200100$ & 0001000000 & 000 \\
\hline Arthrodes xanthopygus & 0000011111 & 0001010000 & 1104100000 & 0101000011 & 1111010000 & 0001100000 & 000 \\
\hline Caelopygus elegans & 0000001110 & 0101010000 & 0100011000 & 0101000011 & 2000000000 & 0001100000 & 000 \\
\hline Caelopygus melanocephalus & 0000011110 & 0101010000 & 0003011000 & 0101000011 & 2000000000 & 0001100000 & 000 \\
\hline Garatiba bocaina & 1110001110 & 1110001130 & 1000000000 & 0101012012 & 2111010000 & 1011100100 & 000 \\
\hline Metampheres albimarginatus & 1000002111 & 0101000000 & 0100000000 & 0011000011 & 3000000000 & 0001100000 & 000 \\
\hline Metarthrodes albotaeniatus & 0000011110 & 0101100011 & 1000100001 & 0101012112 & 3000100000 & 0001100000 & 000 \\
\hline Metarthrodes bimaculatus & 0000001110 & 0001000001 & 1003100000 & 0101012112 & 3000111000 & 0001100000 & 000 \\
\hline Metarthrodes hamatus & 0000111110 & $00 ? 1000011$ & $? 102100001$ & 0101012112 & 2000110000 & 0001100000 & 000 \\
\hline Metarthrodes laetabundus & 0000101110 & 0002000011 & 1202100011 & 0101102111 & 3000011000 & 0011100000 & 000 \\
\hline Metarthrodes leucopygus & 0000011110 & 0001000011 & $? 100101001$ & 0101010112 & 3000101000 & 0001100000 & 000 \\
\hline Metarthrodes longipes & 0000011110 & 0001100011 & 1110100011 & 0101010112 & 1000111011 & 1001100000 & 000 \\
\hline Metarthrodes nigrigranulatus & 0000111110 & 0102000011 & 1110100011 & 0101010112 & 3000111010 & 1001100000 & 000 \\
\hline Metarthrodes pulcherrimus & 0000111110 & 0002100011 & 1111100011 & 0101010112 & 1000210000 & 1001000000 & 000 \\
\hline Metarthrodes xango & 0000002110 & $00 ? 1000011$ & $? 202100001$ & 0101112112 & 3000010000 & 0001000000 & 000 \\
\hline Metarthrodes oxum & $? 000011110$ & $01 ? 1000011$ & $? 110100011$ & 0101012112 & 1000011010 & 1001100000 & 000 \\
\hline Pristocnemis albimaculatus & 2101001110 & 0000000130 & 1101100000 & 1101001011 & 1111010000 & 1101100000 & 000 \\
\hline Pristocnemis farinosus & 2101001110 & 0001000131 & 1001100000 & 1101001011 & 1111010000 & 1101100000 & 000 \\
\hline Pristocnemis perlatus & 2101001110 & 0000000131 & 1111100000 & 0101100011 & $11 ? 1010000$ & 1111100000 & 000 \\
\hline Pristocnemis pustulatus & 2101001110 & 0001000130 & 1003100000 & 0101002011 & 1111010000 & 1111100000 & 000 \\
\hline Pristocnemis caipira & 1101002111 & 0000100131 & 1111100000 & 1101002010 & 1011010000 & $000000 ? 000$ & 000 \\
\hline Thereza albiornata & 1110013110 & 1000001120 & 1100100000 & 0101000011 & 2110001010 & 2000000100 & 000 \\
\hline Thereza amabilis & 1110011110 & 1000001120 & $? 100100000$ & 0101000012 & 1111000011 & 2000000100 & 000 \\
\hline Thereza poranga & 1110011110 & 1000001120 & 1100100000 & 0101000012 & 1111000011 & 2000000100 & 000 \\
\hline Thereza speciosa & 1110011110 & 1000001120 & 1100100000 & 0101000012 & 1111011011 & 2001100100 & 000 \\
\hline Thereza murutinga & $? 100001110$ & $00 ? 0001120$ & $? 100100000$ & 0101001111 & 3100001011 & 2001100100 & 000 \\
\hline Parampheres lucidus & 0000001010 & 0110100000 & 0112111100 & 0010001111 & 2000100000 & 0000000011 & 111 \\
\hline Parampheres pectinatus & 0000000010 & 0110100000 & 0112111200 & 0011001111 & 2000110000 & 0000000011 & 110 \\
\hline Parampheres bimaculatus & 0000001010 & 0110000000 & 0112111200 & $0 ? 10101111$ & 2000100000 & 0000000011 & 100 \\
\hline Parampheres tenebris & 0000001010 & 0110100000 & 0112111200 & 0110001111 & 2000100000 & 0000000011 & 111 \\
\hline Gonyleptes saprophilus & 1000011010 & 0100000000 & 1002010000 & 0110000000 & 3000010000 & 0000000010 & 000 \\
\hline
\end{tabular}


Callampheres Roewer, 1931: 1938 (desc); Mello-Leitão, 1932: 388 (cat, rdes); Soares \& Soares, 1948: 573 (cat). Type species Callampheres boliviensis Roewer, 1931 by monotypy.

Cezarella Mello-Leitão, 1932: 214 (desc); 1935 (key); Soares \& Soares, 1945b; 263 (cit); 1954: 242 (cat); Ringuelet, 1955: 288 (syn Cearinus Roewer, 1929); Capocasale, 1973: 438 (syn Ilhaia Roewer, 1913); Soares \& Soares, 1985 (syst). Type species Cezarella bimaculata Mello-Leitão, 1932, original designation.

Diagnosis. Parampheres resembles some Caelopyginae genera, for example Ampheres Koch, 1839, Caelopygus Koch, 1839, and Proampheres Roewer, 1913, by having rows of tubercles on femur IV (Figs 5-8), the outer apophysis of coxa IV and coloration pattern (Figs 29-31). It resembles Ampheres and Proampheres in the swollen male basitarsus I. It also shares with Proampheres the ocularium armed with spines (or higher tubercles). Parampheres can be easily distinguished from those genera cited above by the presence of two large yellow patches on the sides of the ocularium, the rounded shape of the ocularium (medially depressed in most Caelopyginae) and the presence of the fourth area of the dorsal scutum (Figs 1-4), which is absent in other Caelopyginae.

Composition. Parampheres bimaculatus (Mello-Leitão, 1932), P. lucidus (Mello-Leitão, 1940), P. pectinatus Roewer, 1913 and $P$. tenebris sp. nov.

Redescription. Male. Dorsum. Anterior margin of prosoma with two or three pointed tubercles on angles and a median frontal hump with two or more pointed tubercles. Dorsal scutum densely granulated, with five transversal grooves delimiting four scutal areas (fourth groove is conspicuous only in the middle), scutal area I divided by longitudinal median groove. All areas with a pair of median larger tubercles. Maximal width of dorsal scutum reaching groove IV. Lateral margin of dorsal scutum with two rows of tubercles, from prosoma to posterior margin, generally larger and sharper near groove IV. Posterior margin and free tergites with a row of tubercles, central one larger (Figs 1-4). Chelicerae. Isomorphic in males and females, with 1-3 small tubercles on bulla, fixed finger with five teeth, movable finger with three teeth. Pedipalps. Coxa with two ventral tubercles, trochanter with three ventral tubercles, femur with row of 4-5 ventral tubercles, tarsus biconvex. Legs. Coxa I-III with dorsal tubercles, coxa IV with numerous tubercles on lateral region, a large retrolateral tubercle followed by a row of smaller tubercles and one large prolateral apophysis perpendicular to body axis. Trochanter IIV tuberculated, trochanter IV with a retrolateral row of three tubercles (apical larger), one dorsoapical tubercle and one robust prolateral tubercle. Femur with prolateral and dorsal rows of robust tubercles. Tibia III and IV with two ventral rows of tubercles (Figs 5-8). Distitarsus II 3-segmented. Basitarsus I swollen. Penis. Ventral plate with short and wide cleft on distal margin; lateral margin with three subdistal pairs of large setae, two pairs of reduced setae placed more ventrally; one pair of very small setae of intermediate position; and four pairs of basal (basalmost very reduced) setae. Stylus with cleft, sinuous, thin, long, with subapical trichomes on the apical third of lateral and ventral sides. Presence of a subapical process in $P$. lucidus and $P$. tenebris sp. nov. Ventral process of glans with lateral prominences and longitudinal cleft (Figs 9-16).

Female. similar to male but with much shorter, reduced and conical apophysis on coxa IV. Dorsal scutum narrower, spines on lateral margins, posterior margin and free tergites higher and sharper. Femur IV armature very reduced.

\section{Key to the males of Parampheres}

1. Dorsal apophysis of coxa IV conical and short (Figs 2, 26). Femur IV with a retrolateral row of 3-4 large tubercles increasing in size from base to middle of segment (Fig. 6).... .P. lucidus

1'. Dorsal apophysis on coxa IV elongated and sinuous. Retrolateral row of tubercles along entire femur IV ........ 2

2. Median tubercle on posterior margin about the same size as others in the same row, groove IV conspicuous, femur IV short (femur IV length/dorsal scutum length $=0.9-1.16$ ) (Figs 1, 5, 25, 29). ..P. bimaculatus

2 '. Median tubercle on posterior margin larger than others in the same row, groove IV conspicuous only in the middle, femur IV long (femur IV length/dorsal scutum length $=1.28$ or higher) ... 3

3. Ocularium with two spines (or pointed tubercles), prosoma with yellow marks elongated, dorsal scutum yellow with median region of prosoma, posterior margin and area III brownish (Fig. 28), densely covered with tubercles surrounded with brown patches on areas I and II and lateral margins, claws pectinate (Figs $4,8,28)$.......... P. pectinatus

3 '. Ocularium with two dorsal tubercles, prosoma with yellow marks well delimited, rounded, dorsal scutum entirely dark colored (Fig. 27), with one median row of slightly larger tubercles on area I-III, claws smooth or with ventral margins undulated (Figs 3,7, 27, 31) ................. P. tenebris sp. nov.

\section{Parampheres bimaculatus (Mello-Leitão, 1932)}

$$
\text { Figs 1, 5, 9, 13, 17, 23-25, } 29
$$

Cezarella bimaculata Mello-Leitão, 1932: 214 (desc); B. Soares, 1945a: 370 (cat); Soares \& Soares, 1954: 243 (cat); (female holotype, MNRJ 1388, Pedras Altas, Rio Grande do Sul, Brazil, examined). Cearinus corniger bimaculatus: Ringuelet, 1955: 288 (syst); 1963: 42 (cat); Capocasale, 1966: 631 (cit); 1968: 68 (cit);

Ilhaia bimaculata: Capocasale, 1973: 439 (syst, rdes)

Parampheres bimaculatus: Soares \& Soares, 1985: 161, figs. 3-6 (rdes, syst); Kury, 2003: 135 (cat); Toscano-Gadea \& Simó: 158 (biol); Stanley, 2011: 495 (biol).

Diagnosis. Parampheres bimaculatus resembles P. pectinatus, but it can be distinguished from the latter by the shorter and thicker femur IV with fewer and more agglomerated tubercles, especially on dorsal portion (Figs 5, 8). The claws on tarsi III-IV 

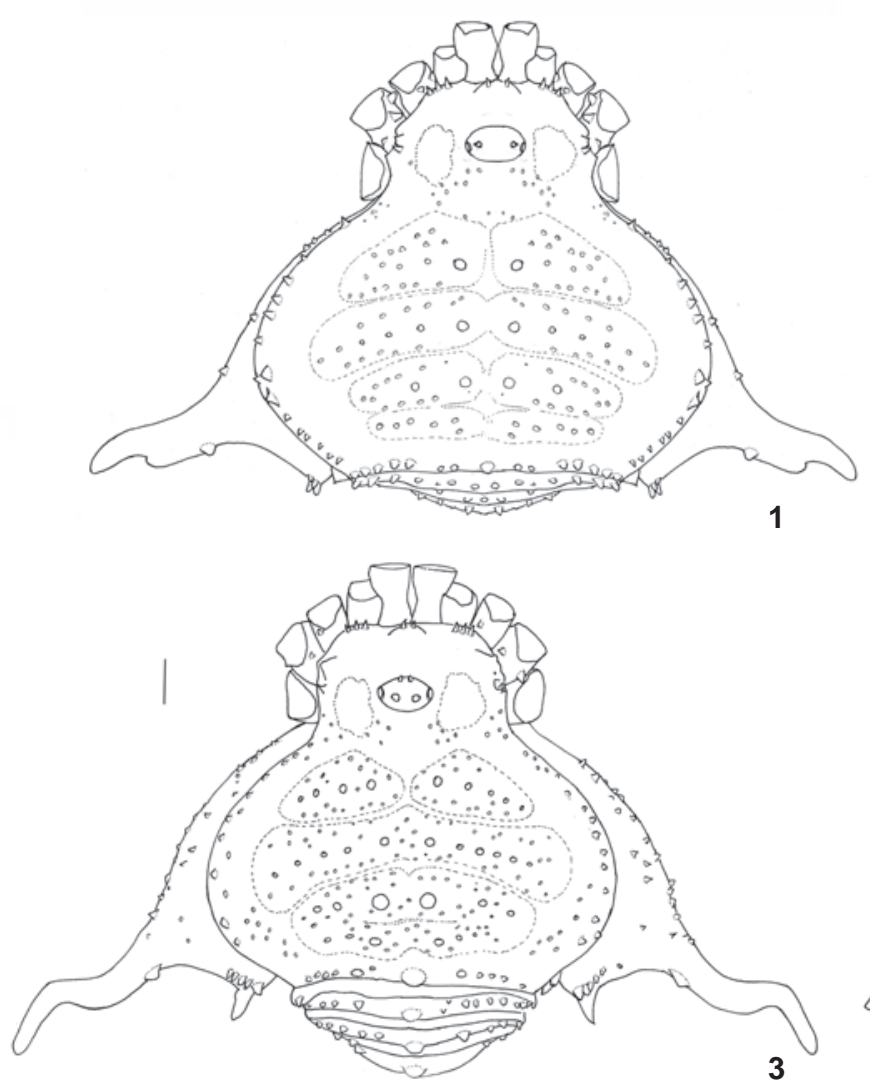
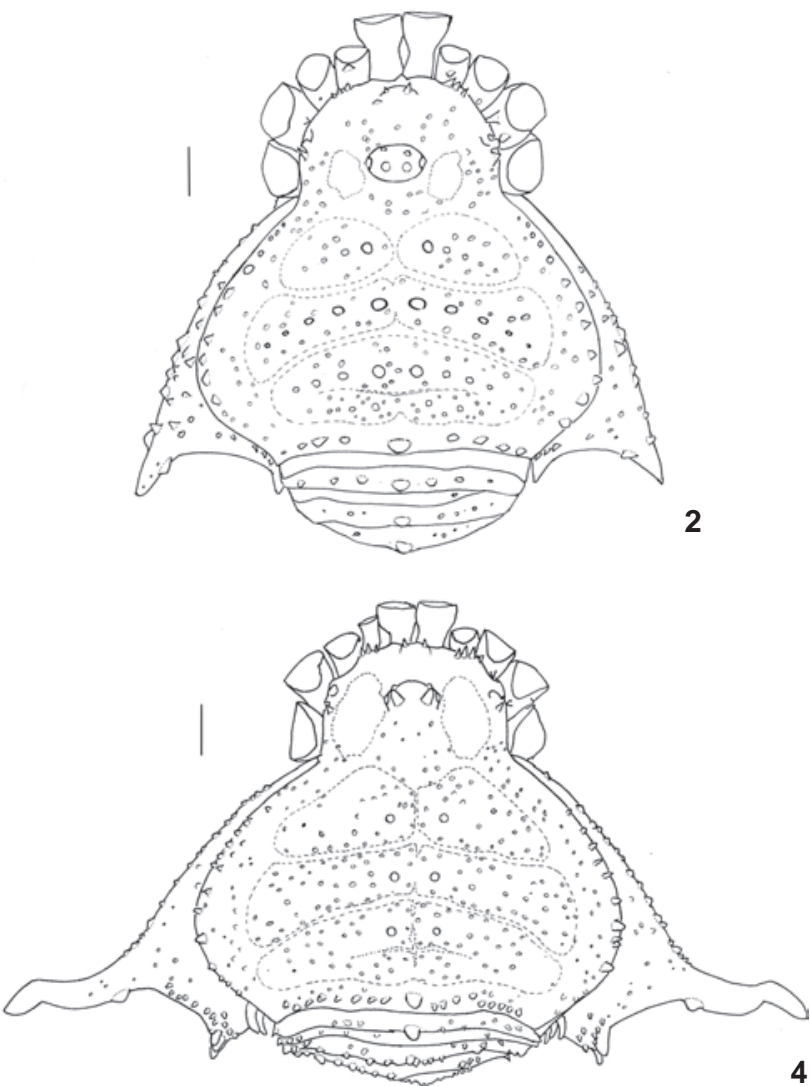

Figures 1-4. Males of Parampheres spp. in dorsal view: (1) P. bimaculatus, MCNRS0726; (2) P. lucidus, MCNRS1615; (3) P. tenebris sp. nov., MCNRS0044; (4) P. pectinatus, MCNRS1364. Scale bars: $1 \mathrm{~mm}$.

are smooth or undulated but not pectinated (Figs 21, 22).There are fewer tubercles on the dorsal areas and they are arranged in a more orderly pattern. The posterior margin of $P$. bimaculatus has a median tubercle about the same size as the others in the same row. In the others species this median tubercle is clearly larger than the others (Figs 1-4). The coloration pattern of P. bimaculatus is usually in shades of brown, brighter than in P. tenebris sp. nov. and $P$. lucidus, but is considerably darker than in $P$. pectinatus. The morphology of the male genitalia is similar to $P$. pectinatus, but in $P$. bimaculatus the trunk of the penis has a distinct process (Fig. 13), which is absent in P. pectinatus (Fig. 16).

Redescription. Male (MCN0726): Measurements. Dorsal scutum: length 7.9; maximum width: 9.1. Prosoma length: 3.3; width: 3.8. Femur IV: length: 8.8. Dorsum (Figs 1, 25). Anterior margin of prosoma with two groups of 2-3 pointed tubercles on each side. Frontal hump with two pointed tubercles. Elevated and rounded ocularium with two anterior, two posterior tubercles, and two high, central (length about twice eye size) tubercles pointing upwards. Two rounded yellow smooth patches, parallel to the ocularium. Area I with 36 , area II with 46, area III with 19 and area IV with 15 tubercles. Most tubercles on areas I and II aligned in three rows of longitudinal tubercles. Area III with two rows and IV with one row. In each area, the central pair of tubercles is larger (largest pair on area III). Lateral margin with two irregular rows bearing 25-26 tubercles, from end of coxa III to posterior margin. Posterior margin and free tergites with a row of tubercles, central tubercle is slightly larger posteriorly. Anal operculum with eight scattered tubercles (Figs 1, 5, 25). Venter. Coxae I-IV uniformly covered with numerous granules. Stigmatic area with few scattered small tubercles. Posterior margin with one row of 15 small tubercles. Free sternites with scattered tubercles. Anal operculum with two rows of small tubercles. Chelicerae. Bulla with three tubercles. Pedipalps. Coxa with two ventral tubercles. Trochanter with three ventral (one larger) and two dorsal tubercles. Femur with a ventral row of five tubercles (basal much larger). Patella unarmed. Tibia setation: mesal - IiiIi/IiIi ectal-iIi. Tarsal setation: mesal Ilii ectal: IiIiii. Legs. Coxa I (dorsum) with one high and one smaller tubercle. Coxa II with one high tubercle, anterior to ozopore and one posterior fused with other of coxa II. Coxa III with one tubercle fused with other of coxa II. Coxa IV with a large retrolateral tubercle followed by a row of smaller dorsal tubercles, one 


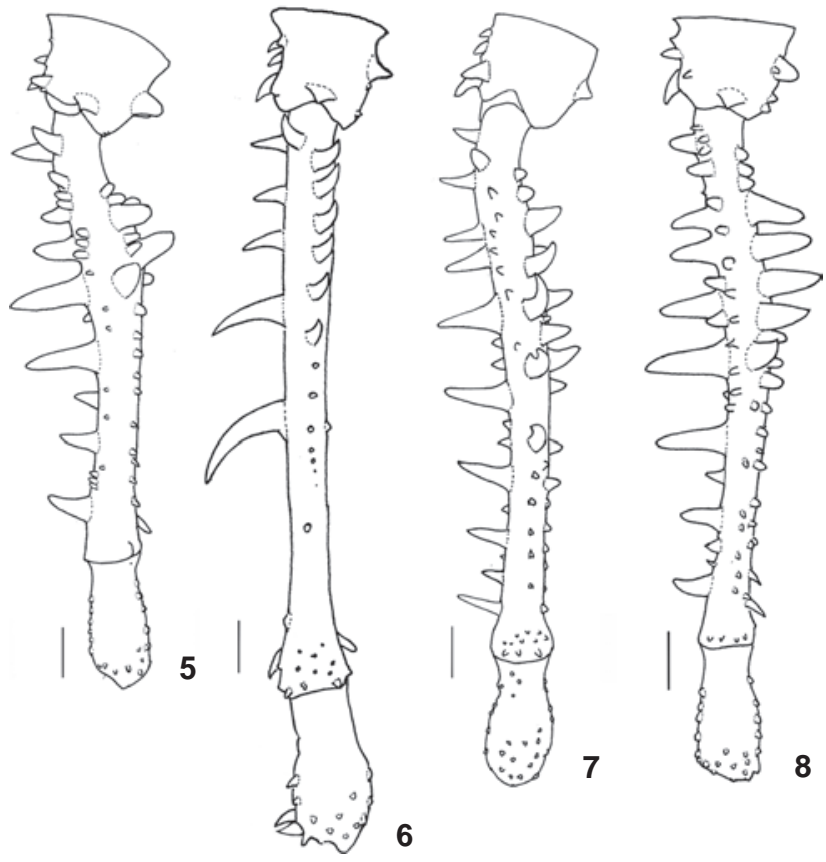

Figures 5-8. Male femora of Parampheres, dorsal view: (5) P. bimaculatus, MCNRS0726; (6) P. lucidus, MCNRS1615; (7) P. tenebris sp. nov., MCNRS0044; (8) P. pectinatus, MCNRS1364. Scale bar: $1 \mathrm{~mm}$.

prolateral apophysis perpendicular to body axis, curved backwards on apical third, pointed down and bearing a posterior basal tubercle. Trochanter I with seven ventral, two retrolateral and three retrodorsal tubercles. Trochanter II with seven ventral, three retrolateral and two retrolateral tubercles. Trochanter III with eleven ventral, five retrodorsal and three retrolateral tubercles. Trochanter IV with several ventral tubercles, two large apical and one small basal tubercles on a retrolateral row, two retrodorsal and one robust pro-dorsal tubercles. Femora I-II tuberculated; III with three rows (two ventral and one retrolateral) of tubercles slightly larger than others. Femur IV (Fig. 5) with a retrolateral row of robust tubercles (larger in middle), a prolateral row of tubercles (larger and clustered in basal region) in all length and three large dorsal tubercles occupying the first third of the segment (two basal pointing upward, third pointing inward). Tibia III-IV with two ventral rows of small tubercles (posterior larger). Tarsal formula: 6, 9(3), 7, 8. Claws smooth (Fig. 21). Tarsal process large, about the same size as claws. Penis (Figs 9, 13, 17). Apical trunk of penis inflated dorsally. Ventral plate with short and wide cleft; lateral margin with three subdistal pairs of large setae, two pairs of reduced setae placed more ventrally; one pair of very small setae intermediate in position; and four pairs of basal setae (basalmost very reduced). Stylus with cleft, sinuous, thin, long, with sub apical trichomes on apical third of lateral, and ventral sides. Ventral process of glans with lateral prominences and longitudinal cleft. Coloration (Fig. 25). In etha- nol: most of body and legs brown yellowish, with brown apophysis on coxa IV and trochanter-tibia IV. Tubercles of dorsal scutum brown. One rounded yellow patch on each side of ocularium. Size variation of males $(n=5)$. Dorsal scutum length: 6.4-7.3; maximum width: 6.7-8.5. Prosoma length: 2.4-2.9; width: 3.3-3.7. Femur IV length: 5.7-8.1.

Redescription. Female (holotype): Measurements: Dorsal scutum: length 6.1; maximum width 6.2. prosoma length: 2,3; width: 3,4. Femur IV length: 6.2. Dorsum (Fig. 29) narrower than in male. Ocularium with two main tubercles and a pair of smaller posterior tubercles. Coxa II with three tubercles, Tibia setation: mesal: IiIi ectal iIi; tarsal setation: mesal: Iiiii ectal: Iilii. Prolateral apophysis of coxa IV very short and conical. Legs III-IV much less armed than in male. Tarsal formula: $6, ?, ?, 8$. Size variation of females $(\mathrm{n}=5)$. Dorsal Scutum length: 6.4-7.3; maximum width: 6.2-7.1. Prosoma length: 5.8-7.8; width: 2.1-2.7. Femur IV length: 5.0-5.9.

Material examined. BraziL, Santa Catarina: Nova Teutônia, 4 ơ, 4 ○ (MNRJ-HS727); Rio Grande do Sul: Santa Vitória do Palmar (Estação Ecológica do Taim), 2 @ (MCNRS-0914); Osório, 1 Ơ (MCNRS-726); Torres, 3 ơ (MCNRS-748); Pedras Altas,1fe (MNRJ-1388); Pelotas, 1 ○’, 1 @ (MNRJ-HS726). URuguay, Artigas: Arroyo de la Invernada, 1 (FCE-Op-310); Canelones, Marindia, 1 ○ (MNHN-272); idem, 1 ○ (FCE-Op-13); idem, 1 ơ (FCE-Op91); idem, 1 ơ (FCE-Op-93); idem, 1 Ơ, 1 ๆ (FCE-Op-173); idem, 2 ९ (FCE-Op-183); idem, Ruta $101 \mathrm{Km} \mathrm{80,} 3$ q (MNHN-782); idem, Salinas, 2 (FCE-Op-166); Maldonado: Cerro Catedral, $2 \sigma^{\star}$ (FCEOp-237); Pta Ballena, 1 ơ (MNHN-11); Pta Este (San Rafael), 5 ○ (MNHN-1093); idem, 2 (MNHN-271); idem, 1 ( $(\mathrm{MNHN}-256) ;$ Rivera: Cuchilla Negra(Aguas Corrientes, Arroyo Cuñapirú), 2 ơ, 1 o (FCE-Op-309); La Palma (Rubio Chico, Ruta 30), 3 ᄋ (MNHN-1235); Ruta27 Km8500, 1 ơ (MNHN-269); Rocha: Bocas del Sarandi, 1 ○ (FCE-Op-163); idem, 1 Ơ (FCE-Op-236); Colonia Don Bosco, 2 ○ (FCE-Op-125); idem, 3 ơ, 1 (FCE-Op-128); Fuerte San Miguel, 1 ơ (FCE-Op-312); La Paloma, 1 ơ (MNHN-115); Potrero Grande, 1 Ơ (FCE-Op-191); idem, 4 ণ̛, 7 ९ (FCE-Op-230); idem, 1 Ơ, 2 ९ (FCE-Op-231); idem, 3 ơ, 4 o (FCE-Op-232); idem, 3 o (FCE-Op-233); Parque Nacional San Miguel, 1 ơ (MNHN1099); Santa Teresa, 1 ○ (MNHN-32).

\section{Parampheres lucidus (Mello-Leitão, 1940)}

Figs $2,6,10,14,18,23,24,26,30$

Penygorna lucida Mello-Leitão, 1940: 22, fig. 24 (desc) (holotype MNRJ 56301, lost).

Arleius lucidus: B. Soares, 1944a: 177 (syst, rdes); Soares \& Soares, 1945a: 222 (cat).

Ilhaia lucida: Soares \& Soares, 1946: 77 (cat); 1949: 187 (cat). Parampheres lucidus: Soares \& Soares, 1985: 171, figs 6-7 (rdes, syst).

Diagnosis. Parampheres lucidus resembles P. tenebris sp. nov. in the coloration pattern (Figs 30, 31) and morphology of the penis. Both species have a subapical process on the stylus. This process is absent in the remaining species of the genus, which only have setae on it (Figs 17-20). Other unique features, ob- 

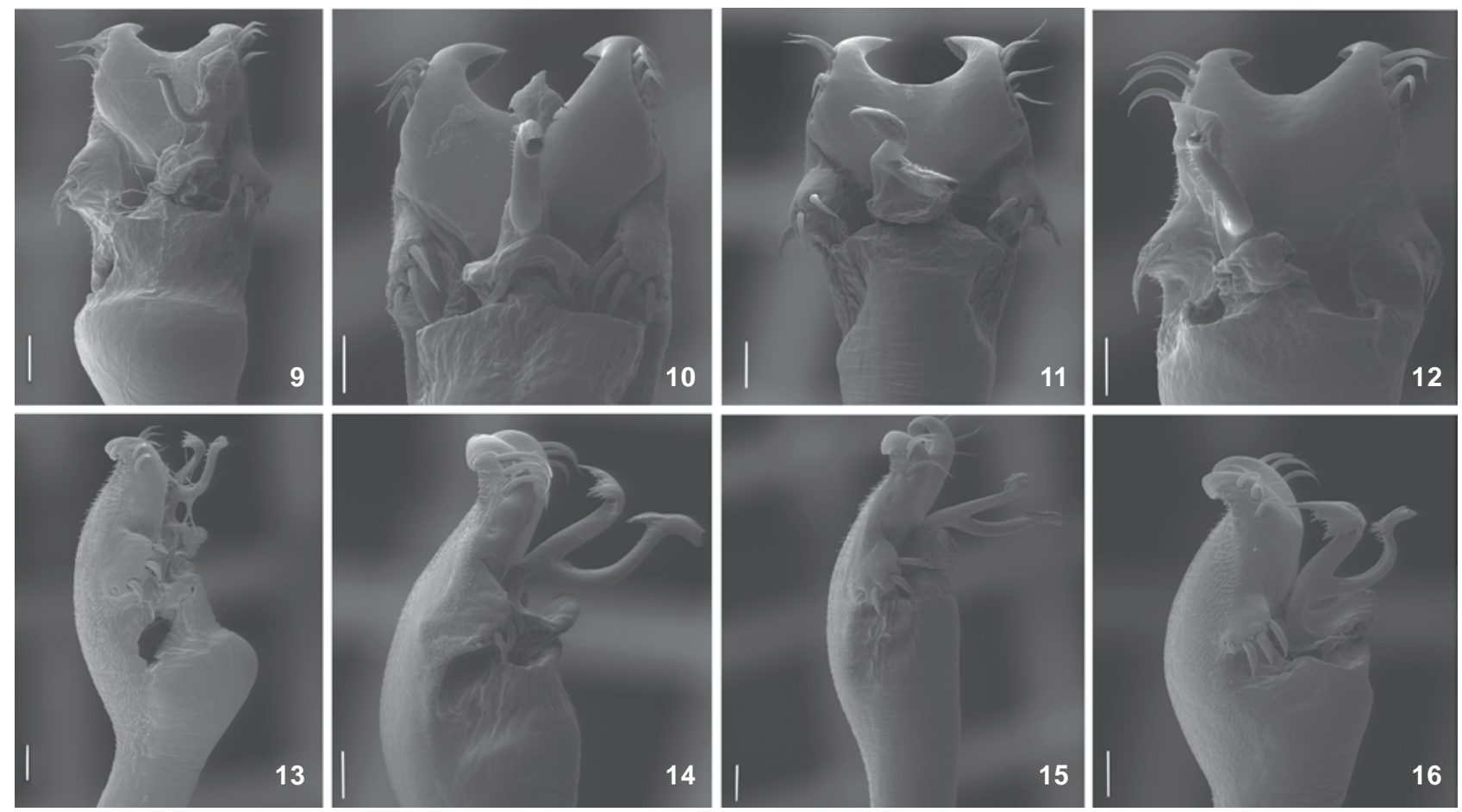

Figures 9-12. Penis of Parampheres. (9-12) Dorsal view: (9) P. bimaculatus, MCNRS0726; (10) P. lucidus, MCNRS1615; (11) P. tenebris sp. nov., MCNRS0044; (12) P. pectinatus, MCNRS1364. (13-16) Lateral view: (13) P. bimaculatus, MCNRS0726; (14) P. lucidus, MCNRS1615; (15) P. tenebris sp. nov., MCNRS0044; (16) P. pectinatus, MCNRS1364. Scale bars: 0.05 mm.
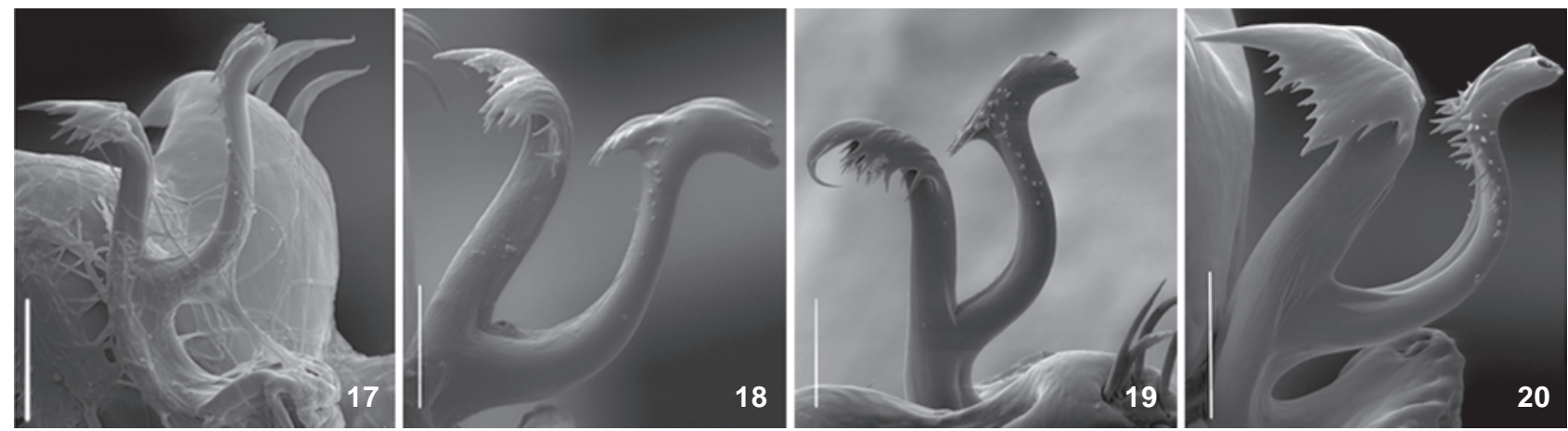

Figures 17-20. Penis of Parampheres., lateral view of stylus: (17) P. bimaculatus, MCNRS0726; (18) P. lucidus, MCNRS1615; (19) P. tenebris, MCNRS0044; (20) P. pectinatus, MCNRS1364. Scale bars: $0.05 \mathrm{~mm}$.

served only in males, are the curved tibia III and relatively short and conical apophysis of coxa IV. P. lucidus also has a characteristic femur IV with a retrolateral row of three or four tubercles, increasing in size apically. This row is limited to the first half of the femur whereas in the other species the retrolateral row is present on the entire segment (this distribution is conspicuous in male but also recognizable in females) (Figs 5-8).

Redescription. Male (MCNRS-1615): Measurements: Dorsal scutum: length: 7.4; maximum width: 8.2. Prosoma length:
2.9; width: 3.9. Femur IV length: 13.5. Dorsum. Anterior margin of prosoma with two groups of four and two pointed tubercles on each side. Frontal hump with four tubercles, two larger and pointed. Elevated and rounded ocularium with four anterior, two posterior, and two larger median tubercles. Two rounded and smooth yellow patches, parallel to the ocularium. Sixteen tubercles in front of and fourteen behind ocularium, sparsely distributed. Four areas, I-III with a row of tubercles (central pair larger) and some randomly dispersed tubercles; IV with only scat- 
tered small tubercles. Tubercle counts: area I - 37; area II - 53; area III - 37; area IV -22 . Lateral margin with two irregular rows of tubercles extending from posterior margin to ozopore. Tubercles larger on outer surface, near area III. Posterior margin and free tergites with a row of tubercles and a larger medium one. Anal operculum with 11 small tubercles in three rows (Figs $2,26)$. Venter. Coxae I-IV uniformly covered with numerous granules. Stigmatic area with a few scattered small tubercles. Posterior margin and free sternites with one row of small tubercles. Chelicerae. One-two dorsal tubercles. Pedipalps. Coxae with two ventral tubercles. Trochanter with three ventral (one larger) and one dorsal tubercle. Femur with 4 tubercles on an irregular longitudinal ventral row and six small dorsal tubercles. Patella unarmed. Tibia setation: mesal IiIi, ectal iiili. Tarsal setation: mesal IIiii, ectal: IiIiii. Legs. Coxa I with a dorsal tubercle, II with two dorsal tubercles. Coxa IV with a large retrolateral tubercle followed by a row of smaller tubercles towards dorsum, one short prolateral apophysis with a sub-apical tubercle. Trochanter I with two ventral tubercles. Trochanter II with thirteen ventral tubercles and two dorsal ones. Trochanter III with seven ventral tubercles and a row of four dorsal tubercles. Trochanter IV with eight ventral tubercles, a retrolateral row of three tubercles, apical larger than the others, one retrodorsal tubercle and one robust prodorsal tubercle. Femora I-II with small tubercles; III with scattered small tubercles and an acute ventral subapical tubercle. Femur IV (Fig. 6) with a retrolateral row of five robust and curved tubercles (posterior two bigger), basal dorsal row of tubercles, one acute basal retrodorsal tubercle and one acute sub-apical prolateral tubercle. Tibia III curved with a cluster of three basal ventral tubercles and one ventral subapical tubercle. Tarsal formula: 6, 11(3), 7, 9. Claws smooth. Penis. Ventral plate with wide cleft on distal margin; lateral margin with three subdistal pairs of large setae, two pairs of reduced setae more ventrally placed; one pair of very small setae on intermediate position; four pairs of basal setae (basalmost very reduced). Stylus with cleft, sinuous, thin, long, with a subapical process, and lateral trichomes. Ventral process of the glans with lateral prominences and a longitudinal cleft (Figs 10, 14, 18). Coloration. In ethanol (Fig. 26): most of body and legs brown, anterior median region of prosoma and femur IV darker. Grooves between dorsal areas, between areas and lateral margin and free tergites dark yellow. One round yellow patch occupying lateral side of ocularium. Two dark brown stripes from posterior margin to free tergite III, one pair of tubercles lateral to the large central one. In vivo (Fig. 30): very dark brown body and legs, patches on the sides of ocularium deep orange. Size variation of males $(n=5)$. Dorsal Scutum length: 7.4-9.0; maximum width: 7.1-9.9. Prosoma length: 2.8-3.6; width: 3.8-4.5. Femur IV length: 10.1-14.6. stopped here

Redescription. Female (MZSP-1627): Measurements. Dorsal scutum: length 8.2; maximum width 7.8. Prosoma length: 2.8; width: 3.7. Femur IV length 9.6. Ocularium with four anterior tubercles. Central tubercles of posterior margin and free tergites acute and higher than in males. Coxa II with three dorsal tubercles. Coxa IV apophysis much smaller than in males. Femur IV armature much less conspicuous than in males, with three spines in retrolateral row. Tibia III almost straight. Tarsal formula $6,10(3), 8,9$. Size variation of females $(n=5)$. Dorsal scutum length: 6.5-7.5; maximum width: 6.9-8.0. Prosoma length: 2.1-2.8; width: 3.3-3.9. Femur IV: 8.9-9.6.

Material examined. BrazIL, Rio Grande do Sul: Serra Geral, 1 Ơ (MZSP-15982); São Francisco de Paula, 1 @ (MCNRS-1630); idem, 1 ○ (MCNRS-1629); idem, 1 (MCNRS-1628); idem, 1 \% (MCNRS-1626); idem, 1 \% (MCNRS-1624); idem, 1 \% (MCNRS,1623); idem, 1 ᄋ (MCNRS-1622); idem, 1 ᄋ (MCNRS1621); idem, 1 q (MCNRS-1619); idem, 1 (MCNRS-1618); idem, 1 ᄋ (MCNRS-1617); idem, 1 ơ (MCNRS-1614); idem, 1 ○ (MZSP1613); idem, 1 ơ (MZSP-916); idem, 8 specimens (MZSP-66270); idem, 13 o (MCNRS-714); idem, 7 ơ (MCNRS-715); idem, 1 \% (MCNRS-1627); idem, 1 ○', 1 (MCNRS-1616); idem, 1 ơ (MCNRS1631); idem, 1 ণ (MCNRS-1620); idem, 1 ণ̛ (MCNRS-1625); idem, 20 (MCNRS-1611); idem, 100 (MCNRS-1615); idem, 10 (MCNRS1612); idem, 1 (MNRJ-7); idem, 7 ơ, 2 ९ (MNRJ-8); idem, 10 ○ (MNRJ-9); idem, 1 ○’, 1 ९ (MCNRS-776); Serra Geral, 1 ๆ (MZSP19370); Mato Grosso, 1 ơ (MNRJ-1484).

\section{Parampheres pectinatus Roewer, 1913} Figs 4, 8, 12, 16, 20, 22-24, 28

Parampheres pectinatus Roewer, 1913: 345 (desc), fig. 136; 1923: 534, fig. 667 (rdes, cat); Mello-Leitão, 1923: 177 (cat); 1932: 386, fig. 248 (cat, rdes); 1933: 147 (cit); B. Soares, 1945a: 349 (cat); Soares \& Soares, 1948: 578 (cat); Ringuelet, 1959: 396, fig. V1-2 (cat, rdes); Soares \& Soares, 1985: 171 (rdes, syst). Acosta \& Maury, 1998: 580 (cat); Kury, 2003: 135 (cat); Pinto-da-Rocha et al., 2012: (= Metapachyloides rugosus Roewer, 1917). (male holotype ZMH, Brazil, São Paulo, Santos; SMF RI825, 3 male and 5 female paratypes from Brazil, Rio Grande do sul, Santa Cruz, examined).

Parampheres tibialis Roewer, 1917: 144, fig. 37 (desc); 1923: 534, fig. 668 (cat, rdes) Roewer, 1931: 136 (cat); Mello-Leitão. 1932: 387, fig. 249 (cat, rdes); Roewer, 1943: 60; Soares \& Soares, 1948: 578, Soares \& Soares, 1985: 171; Kury, 2003: 136 (cat); Pinto-da-Rocha et al., 2012: 54 (male holotype, SMF RI1330, Santos, São Paulo, Brazil, examined). Syn. nov.

Metapachyloides rugosus Roewer, 1917: 121, fig. 22; 1923: 431, fig. 539 (rdesc); Mello-Leitão, 1932: 215, fig. 128 (rdesc); Soares \& Soares, 1946a: 318 (cit); 1954: 276 (cat); Acosta, 1996: 219 (cat). (female holotype, SMF 1322, Santos, São Paulo, Brazil, examined).

Philocrates maculatus Soerensen in schedula, Roewer, 1943: 60.

Pertyana Ronae Mello Leitão, 1927: 18 (desc). (3 males, 4 females syntypes, MNRJ 1385, Caxias, Rio Grande do Sul, Brazil, not examined). Syn. nov.

Pertyana ronae: Roewer, 1930: 422 (cat), 1931: 104 (cat), B. Soares, 1945b: 364 (cat); Soares \& Soares, 1949: 208 (cat).

Pertyana ronnae [misspelling]: Mello-Leitão, 1932: 257, fig. 217 (cat, rdes). 
Parampheres ronae: Soares \& Soares, 1985: 160, figs 1-2 (rdes, syst); Kury, 2003: 136 (cat); Gonzalez et al., 2004: 5 (biol); Stanley, 2011: 495 (biol).

Parampheres nigrimanus Mello-Leitão, 1933: 157, fig. 17 (desc); 1935: 108; Soares \& Soares, 1948: 578 (cat) Soares \& Soares, 1985: 159 (rdes, syst). (female holotype, MNRJ 28144, Rio Grande do Sul, Brazil, not examined).

Penygorna bimaculata Mello-Leitão, 1937: 286, fig. 8 (desc); B. Soares, 1944b: 274 (cat); Soares \& Soares, 1985: 159 (rdes, syst); Coronato-Ribeiro et al., 2013: 505, fig. 5H(cat) (female holotype, IBSP-71, Colônia, Rio Grande do Sul, Brazil, examined).

Arleius bimaculatus: B. Soares, 1945c: 232 (syst). Ilhaia bimaculata: Soares \& Soares, 1946b: 76 (syst). Junior secondary homonym of C. bimaculata Mello-Leitão, 1932.

Ilhaia ringueleti: Capocasale, 1973: 441, fig. 1-5 (rdes, syst). Callampheres boliviensis Roewer, 1931: 138 (desc); Soares \& Soares, 1948: 574 (cat) (female holotype, SMF 1402/13, Chaco, Bolivia, examined). Syn. nov.

Parampheres boliviensis: Kury, 2003: 135(cat).

Parampheres bimaculatus Roewer, 1943: 56, fig. 67; Soares \& Soares, 1985: 159 (rdes, syst) (syntypes SMF RII 6199/19, 3 males, 3 females syntypes; 6198/18 6 males, 7 females syntypes, Nova Teutônia, Santa Catarina, Brazil, examined).

Diagnosis. The external morphology of $P$. pectinatus is similar to $P$. bimaculatus, but there are some discrete differences. The body coloration pattern of $P$. pectinatus is predominantly yellow, with darker areas in the posterior margin and area IV, in contrast with the more uniform and darker brown pattern of $P$. bimaculatus. The yellow patches in $P$. pectinatus are elongated and blend with the body coloration, whereas in $P$. bimaculatus they are rounded and well delimited (Figs 25-28). The male femur IV resembles that of $P$. tenebris sp. nov., but it is thinner, longer, and has more tubercles that are less clustered than in P. bimaculatus (Figs 5-8). The claws in tarsi III-IV are clearly pectinated, a distinctive characteristic within the genus that is apomorfic for Caelopyginae (Figs 21, 22).

Redescription. Male (MCNRS1364): Measurements. Dorsal scutum: length 8.1; maximum width 9.3. Prosoma length: 2.9; width: 3.9. Femur IV length: 12.1. Dorsum. Anterior margin of prosoma with two groups of three pointed tubercles on each side. Elevated and rounded ocularium with four anterior, three posterior tubercles, and two slightly divergent spines pointing upwards. Two large and elongated yellow patches, parallel to the ocularium. Tubercles small and sparsely distributed, mostly found behind ocularium (17), some (6) anterior to it. Yellow patches almost smooth. Four areas densely covered with randomly dispersed tubercles; each area also has a pair of higher tubercles in the center, aligned in a median row in the first three areas. Lateral margin with two irregular rows of tubercles, two larger on outer face, near area III. Posterior margin and free tergites with a row of tubercles and a larger medium one. Anal operculum with three rows of tubercles (Figs $4,28)$. Venter. Coxae I-IV uniformly covered with numerous
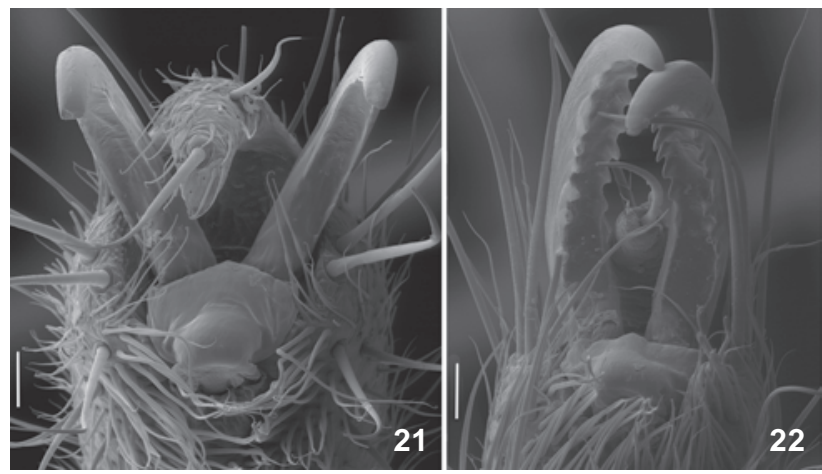

Figures 21-22. Claws of tarsus IV of Parampheres, ventral view: (21) P. bimaculatus, MCNRS0726; (22) P. pectinatus, MCNRS18204. Scale bars: $0.05 \mathrm{~mm}$.

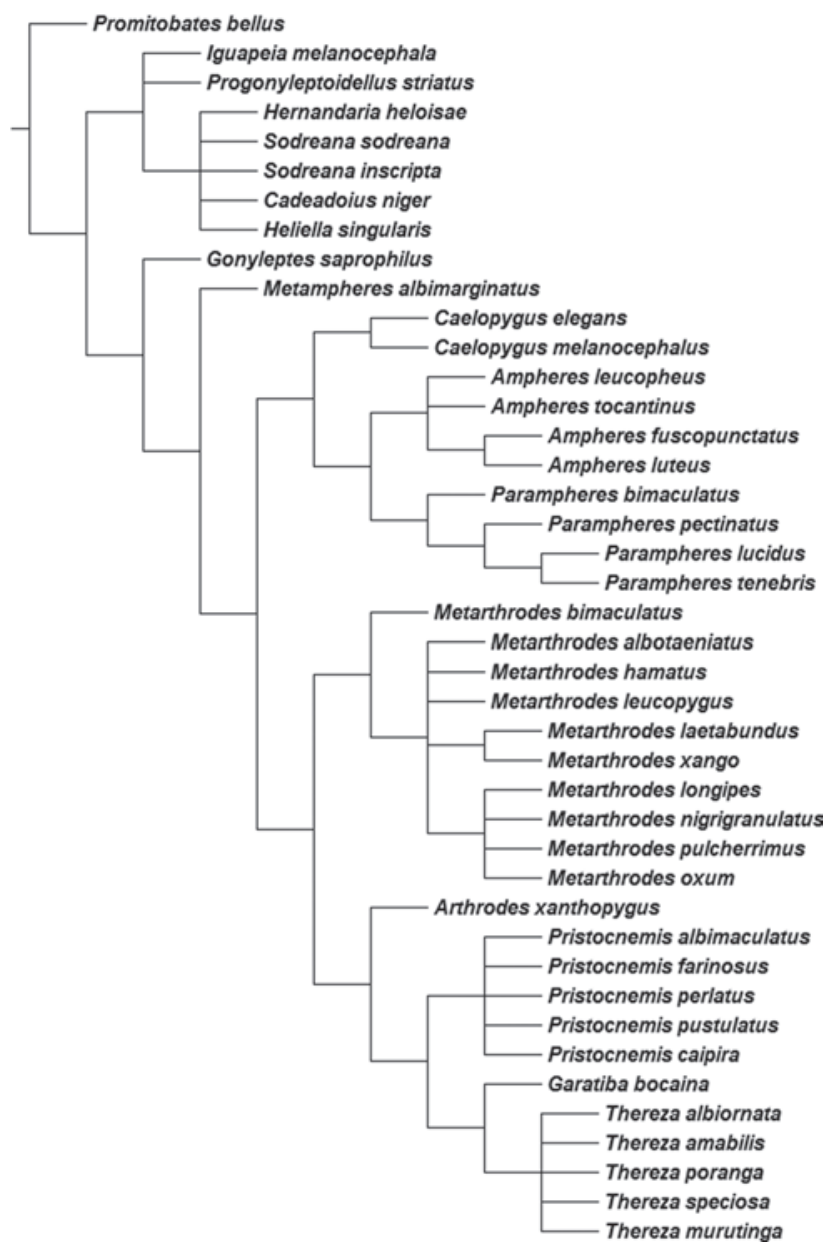

Figure 23. Consensus of 864 equally parsimonious trees (length 235; $\mathrm{Cl}=0.34, \mathrm{RI}=0.72$ ) of Caelopyginae and related taxa, searched using equal weights. The parameter of consensus are length 250 steps, $\mathrm{Cl}=0.32, \mathrm{RI}=0.72$ ). 


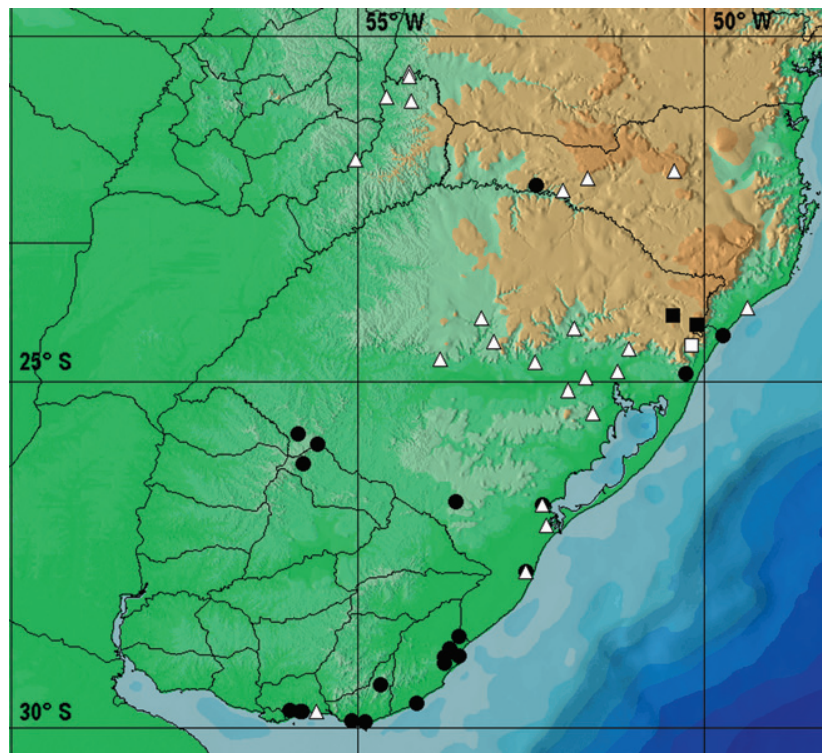

Figure 24. Records of distribution of the four species of Parampheres in East-Southeastern South America: P. bimaculatus ( $)$; P. lucidus $(\square)$; P. pectinatus $(\triangle)$; and P. tenebris sp. nov. $(\square)$.

tubercles. Stigmatic area with a few scattered small tubercles. Posterior margin and free sternites with one row of small tubercles. Anal operculum with eight small tubercles in two rows. Chelicerae. Three granules on bulla of the first segment, second segment with 5 teeth, third with 3 teeth. Pedipalps. Coxa with two ventral tubercles. Trochanter with three ventral (one larger) and three dorsal tubercles. Femur with four tubercles in a longitudinal anterior ventral row and six small dorsal tubercles. Patella unarmed. Tibia setation: mesal IiIi, ectal iiili. Tarsal setation: mesal IiIii, ectal Iilii. Legs. Coxa I with one high and one smaller tubercle; II with one high anterior to ozopore, one smaller, one posterior fused to other of coxa III. Coxa III with one fused with other of coxa II. Coxa IV with a large retrolateral tubercle followed by a row of smaller tubercles dorsally disposed, one long prolateral apophysis, perpendicular to body axis, first half curved frontward with the apical third curved backwards and pointed down. Trochanter I with seven ventral, two retrolateral and three retrodorsal tubercles Trochanter II with seven ventral, three retrolateral and two retrolateral tubercles. Trochanter III with eleven ventral, five retrodorsal and three retrolateral tubercles. Trochanter IV with several ventral tubercles, two large apical and one small basal tubercles on a retrolateral row, two retrodorsal and one robust pro-dorsal tubercles. Femora I-II tuberculated; III with three rows of tubercles slightly larger than the others. Femur IV with a retrolateral row of robust tubercles (larger in middle), a prolateral row of tubercles (larger and clustered in basal region) throughout all length and a dorsal row of high tubercles occupying the first half of the segment (Fig. 8). Tibiae III-IV with two ventral rows of tubercles (posterior larger). Tarsal formula: 6, 10(3), 7, 8. Claws pectinated (Fig. 22). Penis. Ventral plate with short and wide cleft; lateral margin with three subdistal pairs of large setae, two pairs of reduced setae placed more ventrally; one pair of very small setae, intermediate in position; and four pairs of basal setae (basalmost very reduced). Stylus with cleft, sinuous, thin, long, with subapical trichomes on apical third of lateral and ventral sides. Ventral process of glans with lateral prominences and a longitudinal cleft (Figs 12, 16, 20). Coloration (Fig. 28). In ethanol: Most of body and legs yellow, with dark-brown anterior median region of prosoma on areas III-IV. Tubercles of dorsal scutum surrounded by a small brown patch. One elongated yellow patch occupying almost all lateral side of ocularium. In some individuals, dark brown body and legs. Size variation of males $(n=6)$. Dorsal scutum length: 6.1-7.6; maximum width: 6.2-9.0. Prosoma length: 2.6-3.1; width: 3.3-3.9. Femur IV length: 7.4-12.1. Smaller males have tubercles on femur IV shorter than femur diameter, dorsal row of tubercles is reduced to five.

Female (MZSP 18168). Measurements. Dorsal scutum: length 7.9; maximum width 8.3. Prosoma length: 2.9; width: 3.9. Femur IV length 7.6. Lateral margin of dorsal scutum with more acute tubercles. Posterior margin and free tergites with median tubercle higher and sharper than in male, length about same height of the segment. Prolateral apophysis of coxa IV short (slightly smaller than femur IV diameter) and conical, retrolateral apical apophysis slightly longer than in male, with dorsal row of tubercles. Legs III-IV much less armed than in male. Tarsal formula: $6,10,7,8$. Size variation of females $(n=5)$. Dorsal scutum length: 6.5-7.2; maximum width: 6.8-7.8. Prosoma length: 2.6-3.0; width: 3.1-3.6. Femur IV length: 7.3-8.5.

Material examined. BraziL, Santa Catarina: Santa Cecília (BR 116), 2 q (MZSP-18168); Campo Comprido (Catanduva), 1 O', 1 ○ (MZSP-29027); Concordia, 1 Ơ (MZSP-1016); Araguaia (Morro dos Conventos), 1 đ', 1 q (MCNRS-851); Nova Teutônia, 1 ơ (MNRJ-735); idem, 1 ơ, 3 ○ (HS-612); 2 ơ (HS-613); 1 ơ, 6 ㅇ (MNNRJ-4897); Rio Grande do Sul: without locality, 1 Ơ (MNRJ1578); idem, 1 ㅇ (MNNRJ-28144); Canoas (Berto Ciro), 2 o (MCNRS-821); Butiá, 2 ơ, 2 ○ (MCNRS, 750); Rio Grande (Costa Verde), 1 ơ (MZSP-16018); Encantado, (MCNRS-880); Salto do Jacú (Horto CEEE), 1 ơ (MZSP-1364); Morro Reuter, 2 ơ, 3 \% (MZSP-16014); Pelotas, 1 ○ (MZSP-23150); Cambará do Sul (Parque Nacional da Serra Geral), 1 o (MZSP-16722); Quinta, 3 ơ, 2 ९ (MNRJ-17445); Rio Grande (Reserva Taim), in bromeliad, 3 ơ, 11 ᄋ (MZSP-18311); idem, 11 ơ, 15 @ (MZSP-18314); idem, 1 (MCNRS-661); (near Reserva do Taim), 5 ơ, 14 ๆ (MZSP-18204); Santa Maria, 1 ○ (MCNRS-0904); idem, 1 ᄋ (MCNRS-0729); São Francisco de Paula, 1 Ơ, 2 @ (MNRJ-58059); Sertão de Santana, (MCNRS-730); Sobradinho, 1 Ơ (MNNRJ46); Triunfo, 1 ○ (MZSP-1182); idem, 1 ơ (MZSP-1021); idem, 1 ơ (MZSP-0999); idem, 2 ९ (MCNRS-0738); idem, 1 ○゙, 2 ९ (MZSP1040); Vacaria, 3 ơ (MZSP-1260); Santa Maria, 1 ơ (MCNRS727); Sobradinho, 3 ơ, 4 ㅇ (MNNRJ-6). Argentina, Missiones: 
Yacuí, 1 ㅇ (MZCN-32032); Arroyo Uruguaí, 1 ơ, 3 o (MACN4745); Puerto Bemberg, 1 Ơ (MACN-3606); Puerto Rico, 1 ○゙, 1 (MACN); Puerto Yacu, 2 ○ (MACN-3505). Uruguay, Rocha: Palmares de San Luis, 2 ơ, 2 \% (MNHN-212); idem, 2 ơ, 2 \% (MNHN-1170); idem, 4 ơ, 1 ᄋ (FCE-Op-317); Palmares de São Luiz, 2 ơ, 2 ᄋ (MZSP-16052).

Remarks. There are three species with the specific name bimaculata: Cezarella bimaculata Mello-Leitão, 1932; Penygorna bimaculata Mello-Leitão, 1937, and Parampheres bimaculatus Roewer, 1943. The last two are currently under the synonymy of Pertyana ronae, which we now place in synonymy with Parampheres pectinatus. Ilhaia ringueleti was a replacement name created by CAPOCASALE (1973) to avoid secondary homonomy between Penygorna bimaculata and Parampheres bimaculatus, both placed in Ilhaia. With the synonymy of the latter with Pertyana ronae the homonomy ceased to exist and the replacement name has been abandoned (KuRY 2003: 136).

\section{Parampheres tenebris sp. nov.}

\section{Figs 3, 11, 15, 19, 23, 24, 27, 31}

Diagnosis. Parampheres tenebris sp. nov. is similar to $P$. lucidus in the dark color pattern (Figs 30,31). It can be easily distinguished from $P$. lucidus by having an elongated (more than twice trochanter IV length) and sinuous apophysis on coxa IV of the male, contrasting with the short (length less than trochanter IV length) and conical apophysis of $P$. lucidus (Figs 26, 27). Other striking difference is the male femur IV with a retrolateral row of tubercles in $P$. tenebris sp. nov. and three large and spaced tubercles in P. lucidus (Figs 5-8).

Description. Male (MCNRS0044): Measurements. Dorsal scutum: length: 8.1; maximum width: 9.0. Prosoma length: 2.9; width: 4.2; Femur IV length: 11.4. Dorsum. Anterior margin of prosoma with three tubercles on each side. Frontal hump with three pointed tubercles. Ocularium elevated and rounded with two anterior, three posterior tubercles and two larger median tubercles (slightly larger than eye diameter). Two large and round yellow patches, parallel to the ocularium to groove I. Seventeen sparse granules in front and thirteen behind ocularium, yellow patches smooth. Four areas, I to III with a row of tubercles (central pair larger), also some randomly dispersed tubercles and area IV with only small scattered tubercles. Tubercles count: area I-47; area II-58; area III-45; area IV-27. Lateral margin with two irregular rows of tubercles extending from posterior margin to ozopore, tubercles are larger on outer face, near area III. Posterior margin and free tergites with a row of tubercles, with one much larger median. Anal operculum with thirteen small tubercles in three irregular rows (Figs 3, 27). Venter. Coxae I-IV densely covered with tubercles. Stigmatic area with a few scattered small tubercles. Posterior margin and free sternites with one row of small tubercles. Chelicerae. Two dorsal granules on bulla. Pedipalps. Coxa with two ventral tubercles. Trochanter with three ventral and one dorsal tubercle. Femur with four tubercles in longitudinal ven- tral row, five small dorsal tubercles. Patella unarmed. Tibia setation: mesal Iili ectal iili. Tarsal setation: mesal IIiii ectal: Iiliii. Legs. Coxa I with two dorsal tubercles, II with three dorsal tubercles, III with two dorsal tubercles. Coxa IV with numerous tubercles on lateral region, with a large retrolateral tubercle followed by a row of smaller tubercles until apophysis and one long prolateral apophysis perpendicular to body axis, with posterior end curved and pointing backwards. Trochanter I with seven small ventral tubercles and six small dorsal tubercles. Trochanter II with thirteen ventral tubercles and two dorsal ones. Trochanter III with nine ventral tubercles and a row of four dorsal tubercles. Trochanter IV with sixteen ventral tubercles, a retrolateral row of three tubercles, apical larger than the others, dorsoapical tubercle and one robust prolateral tubercle. Femora I-II with scattered small tubercles and a retrolateral row of small tubercles, femur III with two rows of ventral tubercles. Femur IV with a retrolateral row of robust and curved tubercles (larger in the middle), dorsal row of tubercles (much larger in the basal third), prodorsal row of tubercles (larger in the basal third) and a prolateral row of tubercles (posterior ones acute and longer), with dorsoapical reduced tubercles (Fig. 7). Tibiae III and IV with two ventral rows of tubercles (longer near apex). Tarsal formula: 6, 11(3), 7, 9. First article of tarsus I inflated. Claws slightly corrugated. Penis. Ventral plate with short and wide cleft; lateral margin with three subdistal pairs of large setae, two pairs of reduced setae more ventrally placed; one pair of very small setae on intermediate position; four pairs of basal setae (basalmost very reduced). Stylus with cleft, sinuous, thin, long, with a subapical process and lateral trichomes. Ventral process of the glans with lateral prominences and a longitudinal cleft (Figs 11, 15, 19). Coloration (in ethanol, Fig. 27). Most of body and legs light brown with darker apophysis on coxa IV and femur IV. Tubercles slightly darker. One rounded yellow patch occupying each lateral side of ocularium. In vivo (Fig. 31): very dark brown (almost black) body and legs, patches on the side of ocularium deep orange. Size variation of males $(n=3)$. Dorsal scutum length: 7.4-8.7; maximum width: 7.3-9.5. Prosoma length: 3.0-3.2; width: 3.9-4.3. Femur IV length: 9.5-11.9.

Female (MCNRS0044). Measurements. Dorsal scutum: length: 7.8; maximum width: 7.6. Prosoma length: 2.7; width: 3.6; Femur IV length: 9.3. Dorsum. Prosoma with eight small tubercles anterior to ocularium, fifteen posterior to it. Area I 47 tubercles, Area II -52 , Area III - 42, Area IV - 21. Posterior margin and free tergites with a row of tubercles, central tubercles much higher and sharper. Coxa IV prolateral apophysis very short, conical, without helicoidal apex. Legs armor reduced, tubercles shorter and straight. Basitarsus I - not inflated. Tarsal formula: 6, ?, 8, 9. Pedipalps tibial setation: mesal-IiIi ectal-iIi; tarsal station: mesal-IIii, ectal-IiIiii. Size variation of females $(n=5)$. Dorsal Scutum length: 7.4-8.0; maximum width: 7.9-8.5. Prosoma length: 2.7-2.9; width: 3.4-4.1. Femur IV length: 9.3-10.5. 


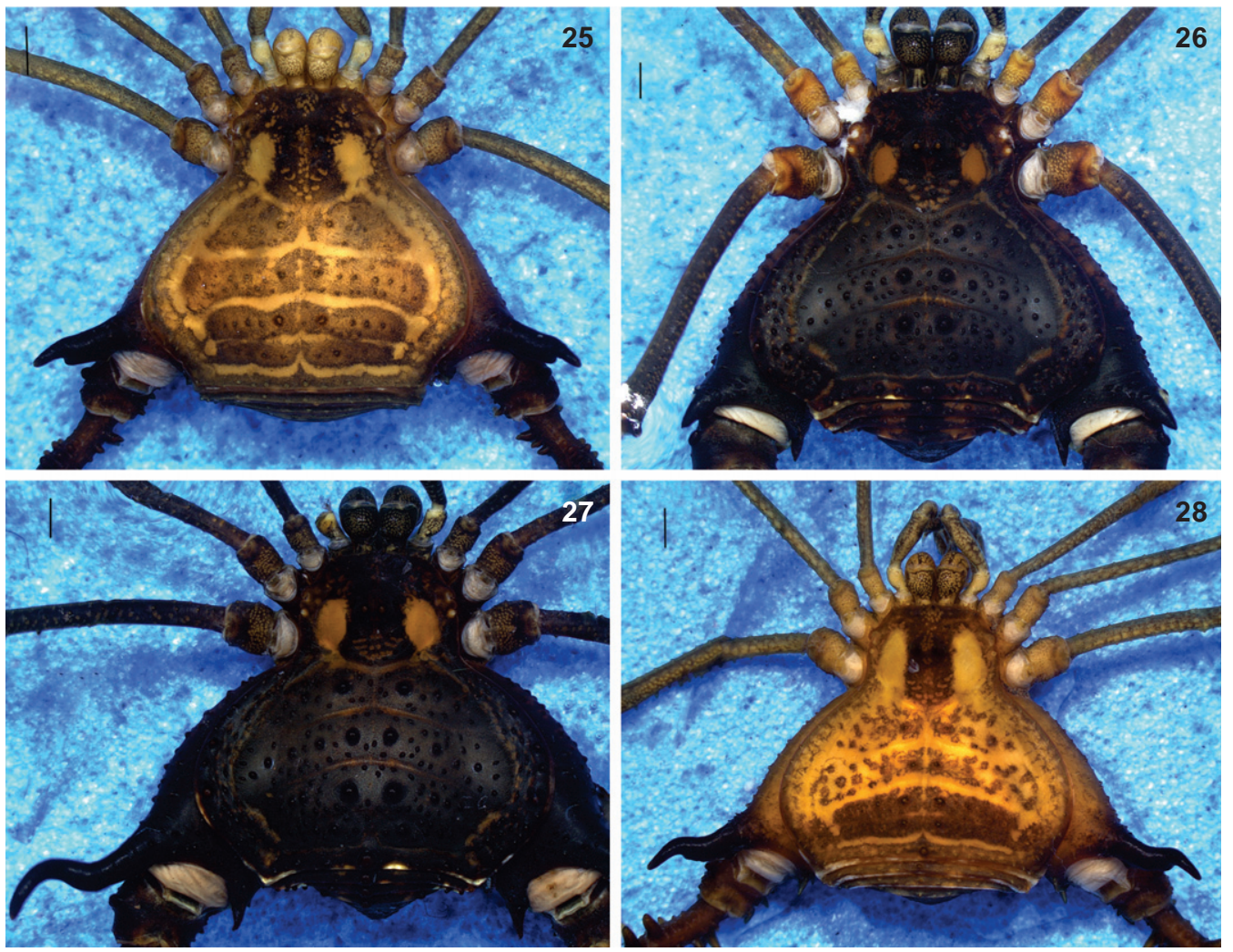

Figures 25-28. Males of Parampheres in dorsal view: (25) P. bimaculatus, MCNRS0726; (26) P. lucidus, MCNRS1615; (27) P. tenebris sp. nov., MCNRS0044; (28) P. pectinatus, MCNRS1364. Scale bars: $1 \mathrm{~mm}$.

Type material. Holotype male from Brazil, Rio Grande do Sul, Cambará do Sul, Parque Nacional Aparados da Serra, (MCNRS-461). Paratypes: same data as holotype; 1 ơ, 1 \% (MCNRS-44); idem, 24.x.2013, A. Benedetti, Y Monteiro \& B. Mori, 1 Ơ (MZSP-66269); idem, 1 @ (MZSP-66271); Itaimbezinho 1 ơ, 6 \% (MCNRS-249).

Etymology. The species epithet, tenebris, is a latin noun that means darkness or shadow. It is given in reference to the dark color of the entire body.

\section{Cladistics}

In the analysis, the four species of Parampheres were included in the matrix of PINTO-DA-Rocha (2002) modified by DaSilva \& Pinto-da-Rocha (2012) and Mendes \& Barros (2013). Eight species of other K92 subfamilies (Progonyleptoidellinae, Gonyleptinae, Sodreaninae and Hernandariinae) were included as outgroups to test the subfamily placement of the genus (see Kury 1992, Caetano \& Machado 2013, Pinto-da-Rocha et al. 2014). The tree was rooted in Promitobates bellus (Mitobatinae), a nonK92 member.

The subfamily placement of Parampheres has been controversial (see introduction), bouncing from Caelopyginae to Gonyleptinae and even Pachylinae. A close relationship between the genera of Caelopyginae was recently recovered in an analysis using four molecular markers (three mitochondrial and one nuclear) and over 100 gonyleptids by PINTO-DA-RochA et al. (2014). The authors included Parampheres bimaculatus and four other Caelopyginae genera and obtained the following relationships for this subfamily: (Ampheres (Parampheres (Arthrodes (Metarthrodes + Pristocnemis))))). According to their hypothesis, the pectinate claws were lost in some species of Parampheres.

The cladistic analysis of morphological characters, under equal weighting, supported the hypothesis that the subfamily is monophyletic and is sister to Gonyleptes saprophilus (Gonyleptinae). The number of synapomorphies supporting Caelopgyinae that are reversed in Parampheres is remarkable. In our analysis, Parampheres is sister to Ampheres. According to this hypothesis, the pectinate claws arose in Caelopyginae and were lost in some species of Parampheres. The shape of the ocularium, widened and with a median depression, was considered synapomorphic for the subfamily by PINTO-DA-RochA (2002). Nevertheless, a rounded and medially high ocularium is present in Parampheres and a similar shape occurs in related groups such as Gonyleptinae and Hernandariinae. Other features, such as the three-segmented distitarsus I (and also tarsal count) and lack of white spots on the anal operculum also 


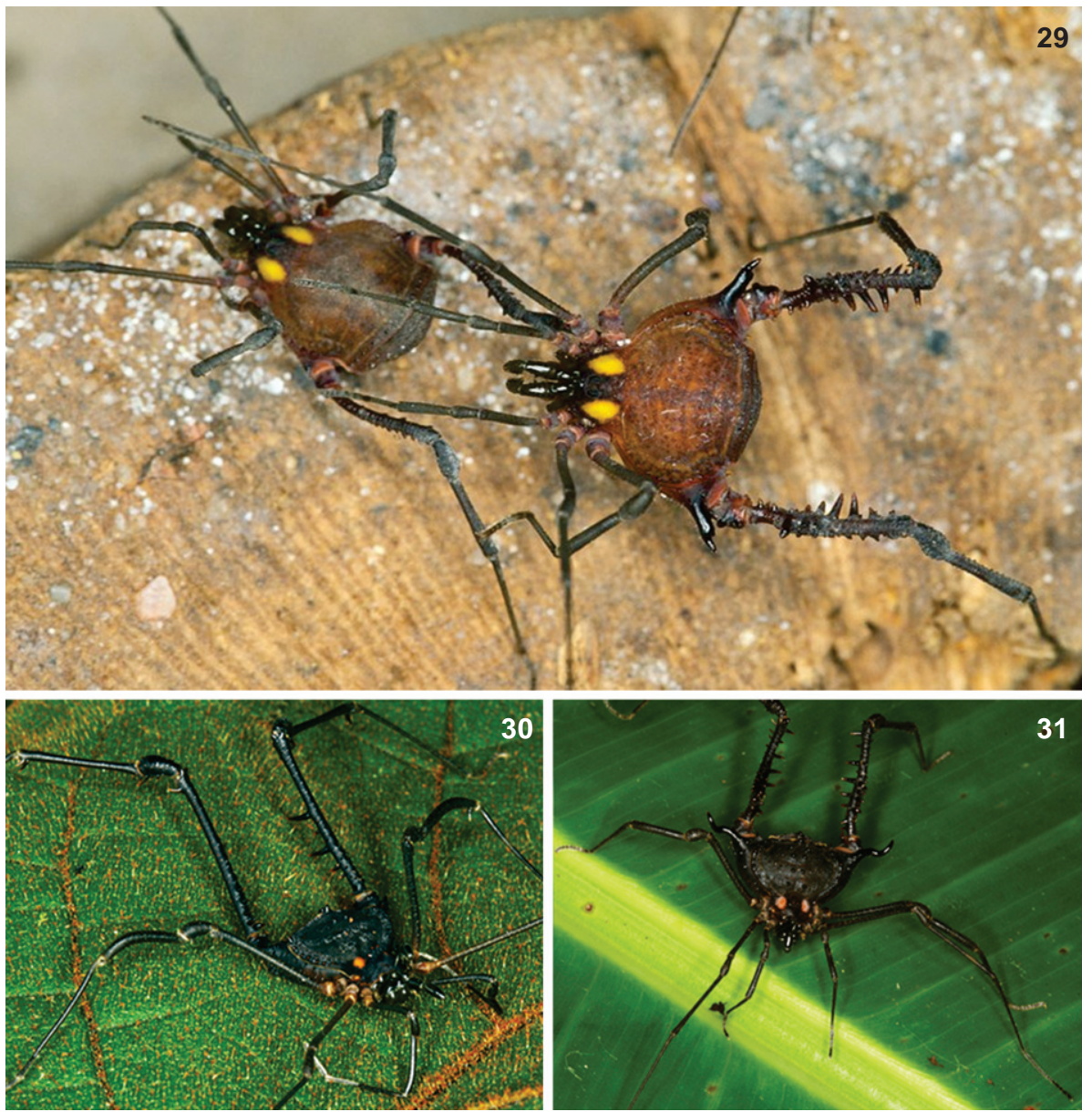

Figures 29-31. Live photographs of three species of Parampheres: (29) male and female of $P$. bimaculatus (photo by Laura Watson); (30) male of $P$. lucidus; (31) male of $P$ tenebris sp. nov.

show reversals in this genus. As a result, the generic placement of species is a somewhat difficult task for a taxonomist who is not familiar with the group. Among the K92 members, only Progonyleptoidellinae and other Caelopyginae genera (including Parampheres) share the moderately long pedipalp with a biconcave tarsus. The Progonyleptoidellinae genera share a short male coxa IV, which is only visible dorsally at the distal portion. On the other hand, the species of Parampheres have a wide male coxa IV.

Parampheres is supported by two non-homoplastic features: the orange-yellow patch on the sides of the ocularium (\#58) and central tubercle on posterior margin of dorsal scutum (\#60). Additionally, ten homoplastic characteristics are non-ambiguous: ocularium rounded dorsally (\#8); armature of female area III with two spines (\#13); posterior margin of dorsal scutum straight (\#14); presence of a long and inner apophysis on male trochanter IV (\#23); male femur IV curved basally only (\#24); distitarsus I three-segmented (\#33); microsetae present on $1 / 3$ of stylus length (\#37); presence of cleft on ventral process of stylus (\#38); dorsal anal operculum without white spot (\#54); and presence of area IV on opisthosoma (\#60). One species of Gonyleptinae, Gonyleptes viridisagittatus, also has a large orangeyellow patch on each side of the ocularium, a rare feature within this subfamily, convergently shared with Parampheres.

Both analyses (molecular and morphological) supported a close relationship of Parampheres with other genera of Caelopyginae. However, these results need to be looked at with caution, since taxon coverage was different in both analyses.

\section{Distribution}

Caelopyginae species occur from Minas Gerais-Bahia (Brazil) to Uruguay, and Parampheres is the southernmost genus of this subfamily. The locality records of Parampheres are in the north-central state of Santa Catarina (Brazil), province of Misiones (Argentina) to Southern Uruguay (Fig. 24). Roewer $(1917,1943)$ reported a much wider distribution, including the 
southeast of Brazil and the Bolivian Chaco. It is noteworthy that Roewer received many donations from various sources of material, but he never participated in any collecting expeditions in South America. This scenario may have facilitated errors in the interpretation of locality labels. It is unlikely that, for example, the holotype of $P$. tibialis is from Santos (state of São Paulo), because the coast of the state is one of the best sampled areas in Brazil and there are no other records of the species from there. Therefore, it is more plausible to believe that this important port city was the site from where the sample was sent to Roewer. Another species of this genus with a questionable type locality is $P$. boliviensis (now $P$. pectinatus). Roewer recorded it from Bolivia, but there are no further records from the Bolivian Chaco.It occurs in Brazil, Argentina (R. Pinto-daRocha, personal obs.) and Paraguay (J. Kochalka personal com.). The considerable distance that separates the Chaco from the remaining locations where the species is found makes us suspect that this record is from a mislabeled sample.

Two species occur in sympatry, Parampheres pectinatus and $P$. bimaculatus. Their ranges encompass the Pampas, Mixed Ombrophilous Forest (known as Brazilian pine forests Araucaria angustifolia) and other formations of the Atlantic Rain Forest.

The other two species of the genus are endemic to a narrow area in the northeastern portion of the state of Rio Grande do Sul. Specimens of Parampheres lucidus, studied by us, are from San Francisco de Paula and vicinities, in northeastern Rio Grande do Sul. However, the type-locality of the holotype is Porto Alegre,the state capital, which is more than $110 \mathrm{~km}$ away. Porto Alegre is a well-sampled location, and there are no additional records of the species from there. We believe that this is another case of mislabeled material sent to Roewer. Parampheres tenebris sp. nov. was found in the Serra Geral National Park, about $80 \mathrm{~km}$ from San Francisco de Paula. The two locations are on the threshold of the Southern Plateau, combining altitudes of approximately $900 \mathrm{~m}$, relatively low temperatures (altitude and latitude) with high moisture supply from the Atlantic Ocean. These conditions favor the development of a nebular forest, where P. lucidus and P. tenebris occur.

\section{ACKNOWLEDGMENTS}

We are grateful to the following curators who provided us material: Peter Jäger (SMF); Arno Lise (MCNRS); Ricardo Ott (MCN-FZRS); Adriano Kury (MNRJ); Miguel Simó. This study is co-funded by FAPESP (BIOTA, 2013/50297-0), NSF (DOB 1343578), and NASA. Carlos Toscano-Gadea and Laura Watson kindly provided color photos from Uruguayan specimens.

\section{LITERATURE CITED}

AcosTA, L.E. 1996. Die Typus-Exemplare der von Carl-Friedrich Roewer beschriebenen Pachylinae (Arachnida: Opiliones: Gonyleptidae). Senckenbergiana Biologica 76 (1/2): 209-225.
Acosta, L.E. \& E.A. Maury. 1998. Opiliones, p. 569-580. In: J.J. MORRONE, \& S.COSCARÓN (Eds). Biodiversidad de Artrópodos argentinos. Una perspectiva biotaxonómica. La Plata, Ediciones Sur.

Caetano, D.S. \& G. Machado. 2013. The ecological tale of Gonyleptidae (Arachnida, Opiliones) evolution: phylogeny of a Neotropical lineage of armoured harvestmen using ecological, behavioural and chemical characters. Cladistics 29 (6): 589-609.doi: 10.1111/cla.12009

Capocasale, R. 1966. Opiliones del Uruguay. Discocyrtus prospicuus Holmberg, el alotipo hembra de Pygophalangodus gemignanii uruguayensis Ringuelet (Gonyleptidae) y Metalibitia rosascostai sp. nov. (Cosmetidae). Bulletin du Museum National d'Histoire Naturelle 37 (4): 631-644.

CAPOCASALE, R. 1968. Nuevos aportes paratypes el conocimiento de la distribucion geografica de los opiliones de Uruguay. Neotropica 14 (44): 65-71.

Capocasale, R. 1973. Opiliones del Uruguay. III: Estudio de tres especies de Laniatores: Ihaia bimaculata (Mello-Leitão,1932) comb. nov.; Ilhaia ringueleti nom. nov. y Pygophalangodus canalsi (Mello-Leitão, 1931) (Gonyleptidae). Physis, C, 32 (85): 437-446.

Coronato-Ribeiro, A.; R. Pinto-da-Rocha \& C. Rheims. 2013. Catalogue of Opiliones (Arachnida) types deposited in the Arachnida and Myriapoda collection of the Instituto Butantan, São Paulo, Brazil. Zootaxa 3637 (5): 501-520. doi: 10.11646/zootaxa.3637.5.1

DaSilva, M.B. \& P. Gnaspini. 2009. A systematic revision of Goniosomatinae (Arachnida: Opiliones: Gonyleptidae), with a cladistic analysis and biogeographical notes. Invertebrate Systematics 23 (6): 530-624. doi: 10.1071/IS09022

DaSilva, M.B. \& R. PinTo-DA-Rocha. 2010. Systematic review and cladistic analysis of the Hernandariinae (Opiliones: Gonyleptidae). Zoologia 27 (4): 577-642. doi: 10.1590/ S1984-46702010000400010

DaSilva, M.B. \& R. Pinto-Da-Rocha. 2012. Descriptions of Thereza murutinga sp. nov. and Pristocnemis caipira sp. nov., and new records of Caelopyginae (Opiliones: Laniatores: Gonyleptidae). Zootaxa 33 (17): 25-38.

GolobofF, P.A.; J. FarRis \& K. NiXon. 2008. TNT, a free program for phylogenetic analysis. Cladistics 24 (5): 774-786. doi: 10.1111/j.1096-0031.2008.00217.x

GonzÁlez, A.; C. Rossilini \& T. EIsner. 2004. Mimicry: imitative depiction of discharged defensive secretion on carapace of an opilionid. Chemoecology 14: 5-7. doi: 10.1007/s00049003-0252-2

HaRA, M.R. \& P. GnASPINI. 2003. Comparative study of the defensive behavior and morphology of the gland opening area among harvestmen (Arachnida, Opiliones, Gonyleptidae) under a phylogenetic perspective. Arthropod Structure \& Development 32 (2-3): 257-275. doi: 10.1016/S1467-8039(03)00040-9

Henriksen, K.L. 1932. Descriptiones Laniatores (Arachnidarum Opilionum Scibordinis). Det Kongelige Danske Videnskabernes Selskab Skriftes 4: 197-422. 
Kury, A.B. 1992. The false Cranainae of the Brazilian Atlantic Forest (Opiliones, Gonyleptidae). Tropical Zoology 5 (2): 279-291. doi: 10.1080/03946975.1992.10539199

KuRY, A.B. 2003. Annotated catalogue of the Laniatores of the New World (Arachnida, Opiliones). Revista Ibérica de Aracnologia 1: 135-136.

KunY, A.B. 2014. Why does the Tricommatinae position bounce so much within Laniatores? A cladistic analysis, with description of a new family of Gonyleptoidea (Opiliones, Laniatores). Zoological Journal of the Linnean Society 172 (1): 1-48. doi: 10.1111/zoj.12165

Mello-Leitão, C.F. 1923. Opiliões Laniatores do Brasil. Archivos do Museu Nacional do Rio de Janeiro 24: 107-197.

Mello-LeITÃo, C.F. 1926. Notas sobre Opiliones Laniatores sulamericanos. Revista do Museu Paulista 14: 327-383.

Mello-Leitão, C.F. 1927. Gêneros novos de Gonyleptideos (Nota previa). Boletim do Museu Nacional do Rio de Janeiro 3 (2): 13-22.

Mello-Leitão, C.F. 1932. Opiliões do Brasil. Revista do Museu Paulista 17 (2): 1-505.

Mello-Leitão, C.F. 1933. Novos Gonyleptidae do Brasil meridional. Archivos da Escola de Agricultura e Medicina Veterinária 10 (2): 133-151.

Mello-Leitão, C.F. 1935. Algumas notas sobre os Laniatores. Arquivos do Museu Nacional do Rio de Janeiro 36 (4): 87 116.

Mello-Leitão, C.F. 1936. Notas sobre opiliões. Boletim do Museu Nacional 12 (3/4): 1-41.

Mello-Leitão, C.F. 1937. Alguns opiliões da collecção do Instituto Butantan. Memórias do Instituto Butantan 11: 275-288.

Mello-Leitão, C.F. 1940. Sete gêneros e vinte e oito espécies de Gonyleptidae. Arquivos de Zoologia do Estado de São Paulo 1 (1): 1-52.

Mello-Leitão, C.F. 1949. Famílias, subfamílias, espécies e gêneros de opiliões e notas de sinonímia. Boletim Museu Nacional Zoologia 94: 1-33.

Mendes, A.C. 2011. Phylogeny and taxonomic revision of Heteropachylinae (Opiliones: Laniatores: Gonyleptidae). Zoological Journal of the Linnean Society 163 (2): 437483. doi: 10.1111/j.1096-3642.2011.00706.x

Mendes, A.C. \& C.M.L. Barros. 2013. Description and phylogenetic position of a new species of Metarthrodes (Opiliones: Gonyleptidae: Caelopyginae) from Bahia, northeastern Brazil. Zoologia 30 (3): 317-323. doi: 10.1590/ S1984-46702013000300009

MuÑoz-Cuevas, A. 1973. Sur les caractères génériques de la familie des Gonyleptidae (Arachnida, Opilions, Laniatores). Bulletin du Muséum National d'Histoire Naturelle (3) 87 (113): 225-234.

NIXon, K.C. 1999. Winclada (BETA). Version 0.9.9. Ithaca, Published by author, Available online at: http://www.cladistics.com/ about_winc.htm [Accessed: 11 november 2013]

PAGE, R.D.M. 2011. NDE. version 0.4.8. Software available online at: http://taxonomy.zoology.gla.ac.uk/rod/NDE/nde.html
PINTO-DA-RochA, R. 2002. Systematic review and cladistic analysis of the Caelopyginae (Opiliones: Gonyleptidae). Arquivos de Zoologia 36 (4): 357-464.

Pinto-Da-Rocha, R. \& C. Bragagnolo. 2010. Systematic revision and cladistic analysis of the Brazilian subfamily Sodreaninae (Opiliones: Gonyleptidae). Invertebate Systematics 24 (6): 509-538. doi: 10.1071/IS10030

Pinto-da-Rocha, R. \& G. Giribet. 2007. Taxonomy, p. 88-246. In: R. Pinto-da-Rocha; G. Machado \& G. Giribet (Eds). Harvestmen: the biology of Opiliones. Cambridge, Harvard University Press.

Pinto-Da-Rocha, R.; A.R. Benedetti; E.G. Vasconcelos \& M.R. Hara. 2012. New systematic assignments in Gonyleptoidea (Arachnida, Opiliones, Laniatores). ZooKeys, 198: 25-68. doi: 10.3897/zookeys.198.2337

Pinto-Da Rocha, R.; C. Bragagnolo; F.P.L. Marques \& M. Antunes. 2014. Phylogeny of harvestman family Gonyleptidae inferred from a multilocus approach (Arachnida: Opiliones). Cladistics 30 (5): 519-539. doi: 10.1111/cla.12065

Ringuelet, R.A. 1955. Noticias sobre los opiliones del Uruguay. Notas Museu de La Plata, Zoologia 18 (163): 279-297.

Ringuelet, R.A. 1959. Clines en opiliones. Un estudio analitico $\mathrm{y}$ biometrico en dos especies de la fauna argentina. Acta Zoologica Lilloana 17: 225-247.

Ringuelet, R.A. 1963. Opiliofauna Uruguaya. Revista de la Sociedad Entomologica Argentina 24: 35-51.

Roewer, C.F. 1913. Die Familie der Gonyleptiden der OpilionesLaniatores. Archive für Naturgescheschichte 79A (4): 1-256.

Roewer, C.F. 1917. 52 neue Opilioniden. Archive für Naturgescheschichte 82A (2): 90-158.

Roewer, C.F. 1923. Die Weberknechte der Erde. Sistematische Bearbeitung der bisher bekannten Opiliones. Jena, Gustav Fischer, 1116p.

RoEWER, C.F. 1929. Weitere Weberknechte III. (3. Ergänzung der: "Weberknechte der Erde", 1923). Abhandlungen der Naturwissenschaftlichen Verein zu Bremen 27 (2): 179-284.

RoewER, C.F. 1930. Weitere Weberknechte IV. (4. Ergänzungder Weberknechte der Erde, 1923). Abhandlungen Naturwissenschaftlichrer verein Bremen 27 (3): 341-452.

RoEWER, C.F. 1931. Weitere Weberknechte V. (5. Ergänzung der Weberknechte der Erde, 1923). Abhandlungen Naturwissenschaftlichrer verein Bremen 28 (2-3): 101-164.

Roewer, C.F. 1943. Über Gonyleptiden. Weitere Webernechte (Arachn., Opil.) XI. Senckenbergiana, 26 (1-3): 12-68.

SoARes, B.A.M. 1944a. Notas sobre opiliões da coleção do Museu Nacional do Rio de Janeiro. Papéis Avulsos do Departamento de Zoologia do Estado de São Paulo 6 (15): 163180.

SoAres, B.A.M. 1944b. Notas sobre opiliões V-XIII. Papéis avulsos do Departamento de Zoologia 4 (17): 243-276.

SoAres, B.A.M. 1945a. Opiliões da coleção do Museu Nacional do Rio de Janeiro. Arquivos de Zoologia do Estado de São Paulo 4 (9): 341-394. 
Soares, B.A.M. 1945b. Opiliões de Porto Cabral. Papéis Avulsos do Departamento de Zoologia do Estado de São Paulo 5 (13): 107-118.

SoAres, B.A.M. 1945c. Revisão dos opiliões do Instituto Butantã. Papéis avulsos do Departamento de Zoologia 5 (25): 227-242.

SOARES, B.A.M. \& H.E.M. SoAres. 1945a. Alguns opiliões do Museu Nacional do Rio de Janeiro. Papéis Avulsos do Departamento de Zoologia do Estado de São Paulo 5 (24): 221-226.

SoAres, B.A.M. \& H.E.M. SoAres. 1945b. Novos opiliões do Departamento de Zoologia da Secretaria de Agricultura do Estado de São Paulo. Papéis Avulsos do Departamento de Zoologia do Estado de São Paulo 5 (27): 251-270.

SoARES, B.A.M. \& SoARes, H.E.M. 1946a. Duas espécies novas de opiliões, p. 315-318. Livro de homenagem a Romualdo Ferreira d'Almeida. São Paulo, Sociedade Brasileira de Entomologia.

Sotres, B.A.M. \& H.E.M. Soares. 1946b. Um novo conceito do gênero Ilhaia Roewer (Opiliones - Gonyleptidae). Papéis avulsos do Departamento de Zoologia 7 (4): 73-78.

SoARES B.A.M. \& H.E.M. SoAres. 1948. Monografia dos gêneros de opiliões neotrópicos I. Arquivos de Zoologia do Estado de São Paulo 5 (9): 553-636.
SoAres, B.A.M. \& H.E.M. Soares. 1949. Monografia dos gêneros de opiliões neotrópicos II. Arquivos de zoologia do Estado de São Paulo 7 (2): 149-240.

SoAres, B.A.M. \& H.E.M. Soares. 1954. Monografia dos gêneros de opiliões neotrópicos III. Arquivos de Zoologia do Estado de São Paulo 8 (9): 225-302.

SoAres, H.E.M. \& B.A.M. Soares. 1985. Opera Opiliologica. Varia. XXII. (Opiliones: Gonyleptidae). Naturalia 10: 157-200.

Sørensen, W. 1884. Opiliones Laniatores (Gonylpetides W. S. olim) Museu Hauniensis. Naturhistorisk Tidsskrift (3) 14: 646.

Stanley, E. 2011. Egg hiding in four harvestman species from Uruguay (Opiliones: Gonyleptidae). Journal of Arachnology 39 (3): 495-496. doi: 10.1636/Hi10-114.1

Toscano-Gadea, C.A. \& M. Simó. 2004. La fauna de opiliones de un área costera del río de la plata (uruguay). Revista Ibérica de Aracnología 10: 157-162.

Yamaguti, H.Y. \& R. Pinto-DA-Rocha. 2009. Taxonomic review of Bourguyiinae, cladistic analysis, and a new hypothesis of biogeographic relationships of the Brazilian Atlantic Rainforest (Arachnida: Opiliones, Gonyleptidae). Zoological Journal of the Linnean Society 156 (2): 319-362. doi: 10.1111/j.10963642.2008.00484.x

Submitted: 17.IX.2014; Accepted: 06.XII.2014.

Editorial responsibility: Antonio D. Brescovit 